\title{
INFLUENCE OF DESIGN AND OPERATING PARAMETERS ON SEPARATING THE COARSE WHEAT BRAN BY CYCLONE
}

\section{Sabbah, F. M.* M. A. Abdel-Hadi** S. M. Radwan** A. S. El-Sayed** ABSTRACT}

Experimental study and predicted models were used to investigate the effect of cyclone geometry and operating parameters such as cone height (30, 50 and $70 \mathrm{~cm})$, vortex finder length $(0,10,20,30$ and $40 \mathrm{~cm})$, dipleg length (25, 40 and $55 \mathrm{~cm})$ and inlet air velocity $(14,16,18$ and $20 \mathrm{~m} / \mathrm{s})$ on separating the coarse wheat bran from air stream. The performance parameters via cut-off diameter $\left(d_{50}\right)$, overall collection efficiency $\left(\eta_{0}\right)$ and pressure drop ( $\triangle P$ ) were evaluated to determine the appropriate design of the cyclone under local operating conditions. The results showed that, $\triangle P$ increased with the increase of inlet air velocity and cone height. The optimum operating and design parameters at cone height of $70 \mathrm{~cm}$ were inlet air velocity $14 \mathrm{~m} / \mathrm{s}$ and vortex finder length $40 \mathrm{~cm}$, which lead to high $\eta_{0} 99.93 \%$ and low $\triangle P 80.63 \mathrm{~Pa}$. While at cone height of $50 \mathrm{~cm}$, the optimum operating and design parameters were: inlet air velocity $18 \mathrm{~m} / \mathrm{s}$ under vortex finder length $40 \mathrm{~cm}$ which lead to high $\eta_{o} 99.97 \%$ and low $\triangle P 121.52 \mathrm{~Pa}$. whereas the cone height $30 \mathrm{~cm}$ and vortex finder length zero $\mathrm{cm}$ were undesirable because they have low $\eta_{o}$. The $d_{50}$ decreased with increase inlet air velocity and lead to increase $\eta_{o}$; for instance at cone height of $30 \mathrm{~cm}$ the $d_{50}$ of Lapple model were 31.95, 29.88, 28.17 and $26.73 \mu \mathrm{m}$ for coarse wheat bran at inlet air velocity 14, 16, 18 and $20 \mathrm{~m} / \mathrm{s}$, respectively. Moreover the statistical indicators presented that the Hoffmann \& Stein model was the best model and more validation to predict coarse wheat bran $\eta_{0}$ at cone height 30 and $50 \mathrm{~cm}$. The Lapple model was the best model and more validation to predict coarse wheat bran $\eta_{0}$ at cone height $70 \mathrm{~cm}$. There is a wide range of the optimum $\eta_{o}$ depend on the design, operating parameters and the price of the separated material and this is subject to the operator's decision; in other words balancing operating economics cost and the price of the separated material.

\footnotetext{
* Ph.D. Student, Agric. Eng. Dept., Faculty of Agric., Suez Canal Univ.

** Prof., Agric. Eng. Dept., Faculty of Agric., Suez Canal Univ., 41522 Ismailia, Egypt.
} 


\section{NOMENCLATURE}

A : cross-sectional areas of the inlet, $\mathrm{m}^{2}$

a : cyclone inlet height, $\mathrm{m}$

b : cyclone inlet width, $\mathrm{m}$

D : cyclone vortex finder (exit pipe) diameter, $m$

$\mathrm{d}_{50} \quad$ : cut-off diameter of particle which is collected with $50 \%$ efficiency, $\mu \mathrm{m}$ or $\mathrm{m}$

$\mathrm{D}_{\mathrm{b}} \quad$ : cyclone cone-tip or dust outlet or dipleg diameter, $\mathrm{m}$

$\mathrm{D}_{\mathrm{c}} \quad$ : cyclone body (cylindrical part) diameter, $\mathrm{m}$

$\mathrm{d}_{\mathrm{c}} \quad$ : core diameter. $\mathrm{M}$

$\mathrm{d}_{\mathrm{pi}} \quad$ : average particle diameter of the ith fraction, $\mu \mathrm{m}$

$f \quad$ : friction factor.

$\mathrm{h}_{1} \quad$ : cyclone cylindrical part (body) height, $\mathrm{m}$

$\mathrm{h}_{2} \quad$ : cyclone conical part height, $\mathrm{m}$

$\mathrm{h}_{3} \quad$ : cyclone dust outlet (dipleg) length, $\mathrm{m}$

$\mathrm{H}_{\mathrm{cs}} \quad$ : height of the control surface extending from the bottom of the vortex finder to the cyclone bottom or core length, $\mathrm{m}$

$\mathrm{H}_{\mathrm{t}} \quad$ : cyclone total height (total height), $\mathrm{m}$

$l \quad$ : physical length, $\mathrm{m}$

$L_{e} \quad:$ distance between the outlet section and the cylindrical barrel top.

$L_{i} \quad:$ distance between the inlet section and the cyclone center.

$l_{n} \quad$ : natural vortex length (inner vortex), $\mathrm{m}$

$\mathrm{M}_{\mathrm{c}} \quad$ : mass of collected dust, $\mathrm{kg}$

$\mathrm{M}_{\mathrm{e}} \quad$ : mass of emitted dust, $\mathrm{kg}$

$\mathrm{M}_{\mathrm{f}} \quad$ : mass of feed dust, $\mathrm{kg}$

$\mathrm{m}_{i} \quad$ : mass fraction of particles in the $i$ th size range, $\%$

$M R D$ : mean relative deviation (statistics), \%

$\mathrm{N} \quad$ : number of cyclones in the system, in parallel.

$n \quad$ : number of measurements (statistics).

$\mathrm{N}_{\mathrm{e}} \quad$ : number of effective turns in a cyclone

$P_{s i} \quad$ : static pressure at inlet, $\mathrm{N} / \mathrm{m}^{2}$

$P_{s o} \quad$ : static pressure in outlet, $\mathrm{N} / \mathrm{m}^{2}$

Q : gas volume flow rate, $\mathrm{m}^{3} / \mathrm{h}$ or $\mathrm{m}^{3} / \mathrm{s}$

$\mathrm{R} \quad$ : cyclone radius $\left(\mathrm{D}_{\mathrm{c}} / 2\right), \mathrm{m}$

$\mathrm{r} \quad$ : Pearson correlation coefficient (statistics).

$\mathrm{R}_{\mathrm{d}} \quad$ : radius of dust outlet or dipleg $\left(\mathrm{D}_{\mathrm{b}} / 2\right), \mathrm{m}$

$R M S E \quad$ : root mean square error (statistics)

RSEP : relative standard error of prediction (statistics), \%

$\mathrm{R}_{\mathrm{x}} \quad$ : radius of vortex finder $(\mathrm{D} / 2), \mathrm{m}$

$\mathrm{S} \quad$ : cyclone vortex finder or gas outlet length, $\mathrm{m}$

$\mathrm{V}$ : flow velocity in streamwise direction, $\mathrm{m} / \mathrm{s}$

$v_{i} \quad$ : average air velocity at the cyclone inlet, $\mathrm{m} / \mathrm{s}$

$\mathrm{v}_{\text {rcs }} \quad$ : redial velocity at control surface, $\mathrm{m} / \mathrm{s}$

$\mathrm{V}_{\mathrm{t} \max } \quad$ : maximum air tangential velocity, $\mathrm{m} / \mathrm{s}$

$\mathrm{v}_{\theta \mathrm{cs}} \quad$ : tangential velocity at the control surface $\mathrm{CS}, \mathrm{m} / \mathrm{s}$

$\mathrm{v}_{\theta \mathrm{w}} \quad$ : wall velocity (the velocity outside CS), $\mathrm{m} / \mathrm{s}$

$x \quad$ : experimental value.

$y \quad$ : predicted value.

$\beta \quad$ : slope parameter. 


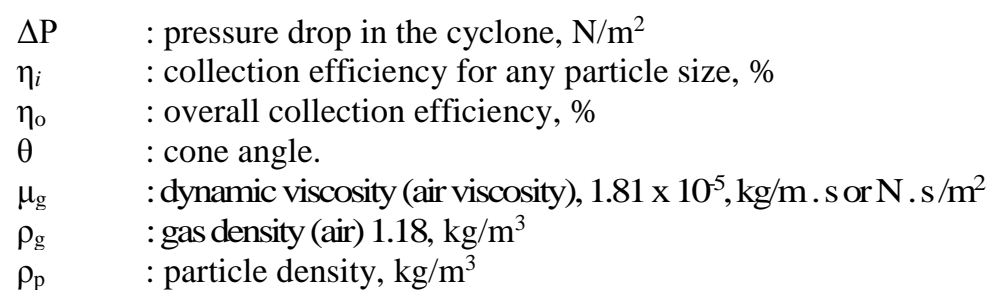

\section{INTRODUCTION}

any industrial sectors like food and fodder processing,
agricultural processing, minerals processing, plastic and
chemical industry and many more run processes contained huge amounts of particles or powder in their processes. Particulate matter or powders are tiny particles of solid particle suspended in a gas (Juengcharoensukying $\boldsymbol{e t}$ al., 2017). Cyclone is still the most popular cleaning device used in many industries to separate particulate matter from process gas streams. Cyclone is considering a simple device that uses centrifugal force to separate the particles from the conveying gas (Hoffmann and Stein, 2008). In spite of the principle of the cyclone separators is simple, the flow of the mixture inside the cyclone is very complex. So, many experimental, theoretical and computational studies have been reported in the literature aimed understanding, predicting and improving the performance of cyclones in terms of pressure drop and overall collection efficiency (Elsayed, 2011).

Chuah et al. (2003) concluded that pressure drop is a function of the square of inlet velocity, so too high a velocity will cause an excessive pressure drop. On the other hand, too low a velocity would cause a low efficiency. A very high inlet velocity would decrease the collection efficiency because of increasing turbulence and re-entrainment of particles. Generally it was found that the optimum operating velocity is around $18 \mathrm{~m} / \mathrm{s}$. Meanwhile, Shepherd and Lapple (1939) reported that, the range of practicable cyclone inlet velocity is around $15-30 \mathrm{~m} / \mathrm{s}$. Moreover Wang et al. (2006) used inlet velocity of the mixture (gas particle) $20 \mathrm{~m} / \mathrm{s}$. Abdel-Hadi (2014) investigated the effect of inlet air velocity on the flow field behavior and performance of the cyclone to separate coarse wheat bran, the results showed that, the overall collection efficiency was function to increase inlet velocity in the range from 9.3 to $18.5 \mathrm{~m} / \mathrm{s}$. The best inlet velocity was $18.5 \mathrm{~m} / \mathrm{s}$ where the overall 
collection efficiency values were $96.4,98.9,98.5,98.3$ and $98.7 \%$; the pressure drop values were $1173,1324,1249,1137$ and $1419 \mathrm{~Pa}$ at vortex finder lengths $0,5,10,15$ and $20 \mathrm{~cm}$, respectively. The pressure drop in a cyclone is the difference of static pressure between the inlet and outlet, which can be written as follows according to (Chen and Shi, 2007):

$$
\Delta P=P_{s i}-P_{\text {so }}
$$

Azadi et al. (2010) reported that, cyclones are characterized by cut-off diameter $\left(\mathrm{d}_{50}\right)$ which defines the particle size for which the cyclone collection efficiency is $50 \%$. It is important to know the cyclone cut-off diameter under certain operational conditions and geometry. Traditional cyclone literature has given direct empirical correlations for $\mathrm{d}_{50}$ based on the cyclone geometry and flow properties as listed in Table (1).

Table (1): Traditional cyclone literature for cut-off diameter (d50).

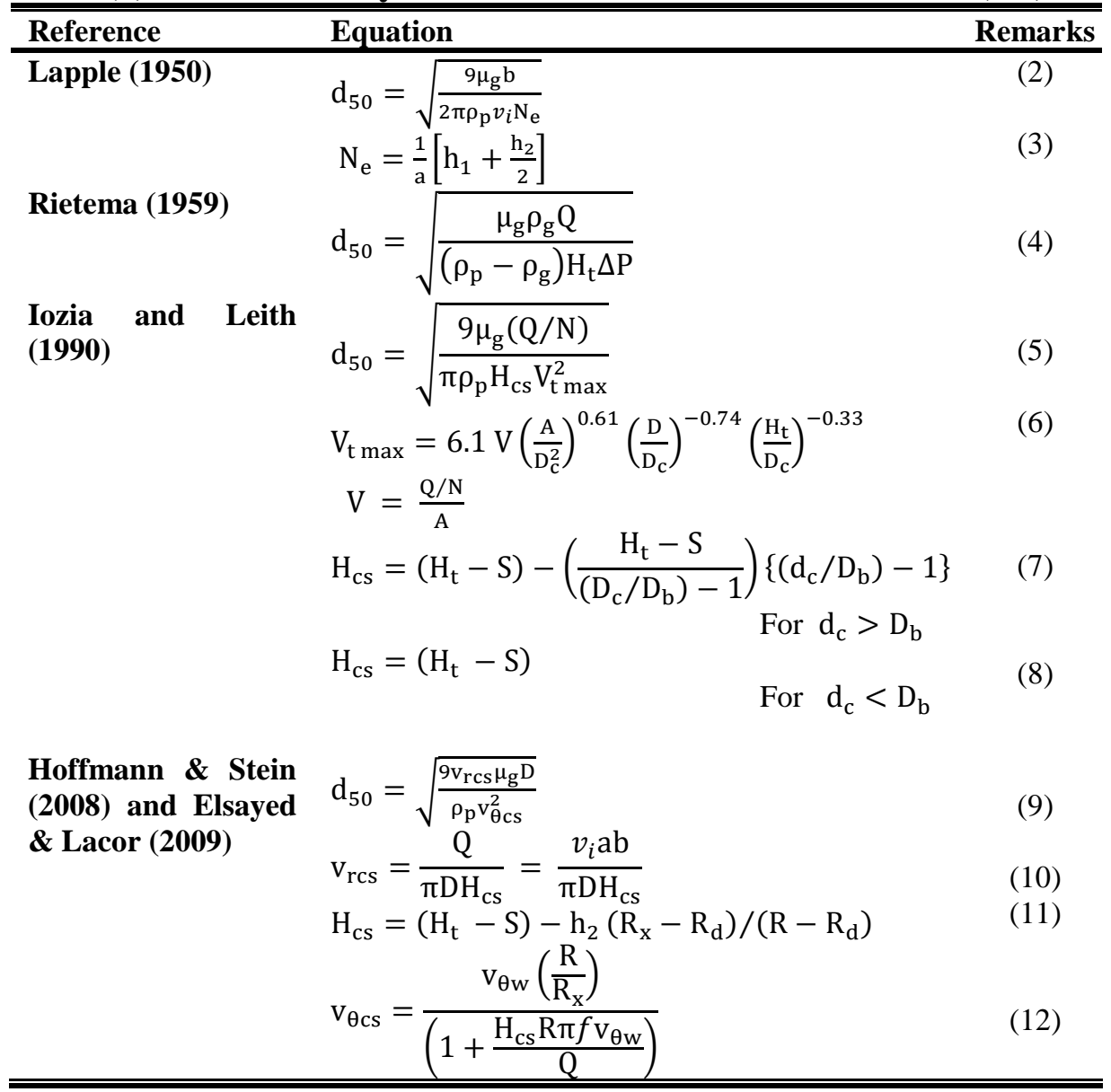


The main performance characteristics of cyclone separators are fractional efficiencies $\left(\eta_{i}\right)$ and overall collection efficiency $\left(\eta_{\mathrm{o}}\right)$. Fractional efficiency is defined as the fraction of particles of a given size collected in the cyclone, compared to those of that size going into the cyclone. it can be expressed as a function of particle diameter $\left(d_{p i}\right)$. Several equations have been developed to predict the fractional and overall collection efficiency in cyclones through correlation equations as listed in Table (2).

Table (2): Literature equations for predict the fractional and overall collection efficiency in cyclones.

\begin{tabular}{lll}
\hline \hline Reference & Equation & Remarks \\
\hline $\begin{array}{ll}\text { Lapple } \\
\begin{array}{l}\left(\mathbf{1 9 5 1} \mathbf{1}_{\mathbf{a}}\right) \\
\text { Iozia and }\end{array}\end{array}$ & $\eta_{i}=1 /\left[1+\left(\frac{d_{50}}{d_{p i}}\right)^{2}\right]$ \\
Leith (1990) & $\eta_{i}=\frac{1}{1+\left(d_{50} / d_{p i}\right)^{\beta}}$ & \\
Where: & $\ln (\beta)=0.62-0.87 \ln \left[d_{50}(\mathrm{~cm})\right]+5.21 \ln \left(\frac{A}{D_{c}^{2}}\right)+1.05\left[\ln \left(\frac{A}{D_{c}^{2}}\right)\right]^{2}$
\end{tabular}

Zhu and Lee (1999) reported that the physical length played a significant role in the particle collection characteristics, so the vortex finder length could be optimized. The outer vortex weakens and changes its direction at a certain axial distance $\left(l_{\mathrm{n}}\right)$ from the vortex finder. This distance is usually called the natural length of the cyclone as shown in Fig. (1) (Wang et al., 2003 and Cort'es \& Gil, 2007). A good cyclone separator design has equal natural vortex length $\left(l_{n}\right)$ and physical length $\left(l=\mathrm{H}_{\mathrm{t}}-\mathrm{S}\right)$; overall length of the barrel and cone minus the vortex finder length (Swaray and Hamdullahpur, 2004). Büttner (1999) found two distinct types of cyclone operation. First type, when the operation with $l_{n} \geq l$; the vortex end reaches the bottom of the cyclone. Second type, when the operation with $l_{n}<l$ the collection performance is poor, because the vortex end attaches to the cyclone wall, disturbing the solids strands that are already separated and decreasing the efficiency through instability and re-entrainment. Table (3) shows different correlation used to calculate the natural vortex length of the cyclone. 


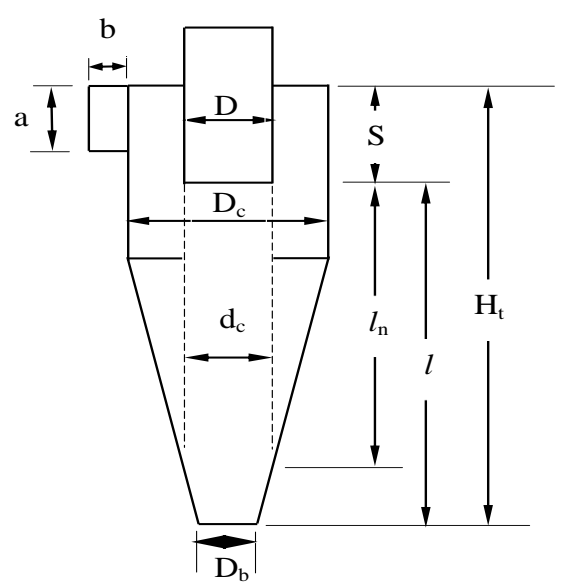

Fig. (1): Cyclone inner vortex core dimensions (Wang et al., 2003).

Table (3): The empirical models in the literature used for calculating the natural vortex length of the cyclone.

\begin{tabular}{ccc}
\hline \hline Reference & \multicolumn{1}{c}{ Equation } & Remarks \\
\hline Alexander (1949) & $\frac{l_{n}}{D_{c}}=2.3 \frac{D}{D_{c}}\left(\frac{D_{c}^{2}}{A}\right)^{1 / 3}$ \\
Bryant et al. (1983) & $\frac{l_{n}}{D_{c}}=2.26\left(\frac{D}{D_{c}}\right)^{-1}\left(\frac{D_{c}^{2}}{A}\right)^{-0.5}$ \\
Ji et al. (1991) & $\frac{l_{n}}{D_{c}}=2.4\left(\frac{D}{D_{c}}\right)^{-2.25}\left(\frac{D_{c}^{2}}{A}\right)^{-0.361}$ \\
\hline \hline
\end{tabular}

The main objectives of this study are to investigate the effect of cyclone geometry and operating parameters such as cone height, cyclone total height, vortex finder length, dipleg length and inlet air velocity on performance parameters via $\mathrm{d}_{50}, \eta_{\mathrm{o}}$ and $\Delta \mathrm{P}$. Assess the predictive validity of some literature correlations in comparison with the measured data to put the data into better use with the existing theories.

\section{MATERIALS AND METHODS}

\section{Experimental Setup}

The experimental unit was designed and constructed at the workshop of the Agricultural Engineering Department, Faculty of Agriculture, SuezCanal University. The parts of unit were fabricated from galvanized steel sheet of $1.5 \mathrm{~mm}$ thickness. Cutting and welding of cyclone parts were done by laser technology in a local workshop in $10^{\text {th }}$ of Ramadan city 
industrial. The dimension and specification of the experimental unit are tabulated in Table (4) and the overview in Fig. (2). The inclined differential water-manometer for pressure drop measurement was made from the silicone tube internal and external diameter of 6.5 and $9.5 \mathrm{~mm}$, respectively. The differential water-manometer was fixed between inlet and outlet air as shown in Fig. (2). The air supply unit was connected to the air inlet pipe and a set of input dust particle. The air velocities $(\mathrm{m} / \mathrm{s})$ were measured by air velocity meter.

Table (4): Dimension and specification of the experimental setup.

\begin{tabular}{cllc}
\hline \hline Parameter & Description & Values & Unit \\
\hline \hline $\mathrm{D}_{\mathrm{c}}$ & Cyclone body diameter & 30 & $\mathrm{~cm}$ \\
$\mathrm{~h}_{1}$ & Cyclone cylindrical part height & 50 & $\mathrm{~cm}$ \\
$\mathrm{~b}$ & Cyclone inlet width & 7.2 & $\mathrm{~cm}$ \\
$\mathrm{a}$ & Cyclone inlet height & 7.2 & $\mathrm{~cm}$ \\
$\mathrm{D}$ & Vortex finder diameter & 9.2 & $\mathrm{~cm}$ \\
$\mathrm{D}_{\mathrm{b}}$ & Dipleg diameter & 7.7 & $\mathrm{~cm}$ \\
Experimental parameters under study & & \\
$\mathrm{h}_{2}$ & Cyclone conical part height & 30,50 and 70 & $\mathrm{~cm}$ \\
$\mathrm{~h}_{3}$ & Dipleg length & 25,40 and 55 & $\mathrm{~cm}$ \\
$\mathrm{H}_{\mathrm{t}}$ & Cyclone total height & 80,100 and 120 & $\mathrm{~cm}$ \\
$\mathrm{~S}$ & Vortex finder length & $0,10,20,30$ and 40 & $\mathrm{~cm}$ \\
$v_{i}$ & Inlet air velocity & $14,16,18$ and 20 & $\mathrm{~m} / \mathrm{s}$ \\
\hline \hline
\end{tabular}

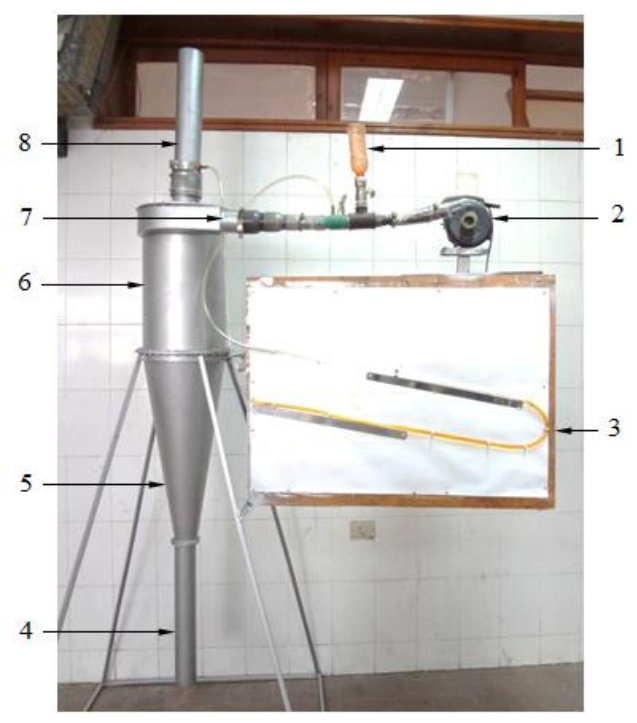

(A)

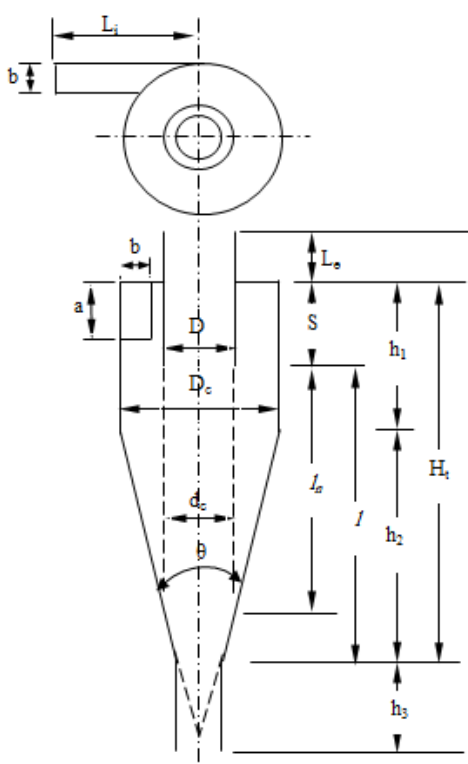

(B)

Fig. (2): Cyclone annexed to the water-manometer (A) anu uesign \& nomenclature (B). 
The bulk density of coarse wheat bran was determined in laboratory, it was $213 \mathrm{~kg} / \mathrm{m}^{3}$. The obtained result of coarse wheat bran was in range bulk density from 176 to $256 \mathrm{~kg} / \mathrm{m}^{3}$ according to (Appel, 1985). The particle size distribution were measured using a vibrating sieve shaker machine consists of sieves stacked vertically with sizes ranging from 60 to $2500 \mu \mathrm{m}$. The percentage of full-size distribution for average particle diameter $(\mu \mathrm{m})$ is shown in Fig. (3).

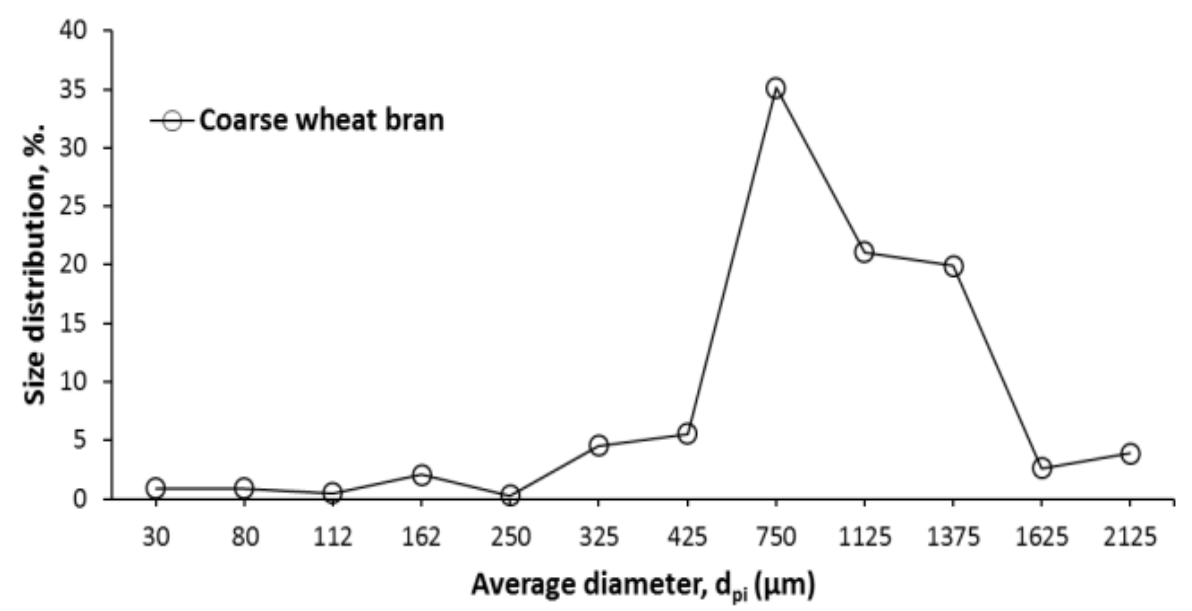

Fig. (3): The percentage of full- size distribution for coarse wheat bran.

\section{Overall Collection Efficiency Measurements $\left(\boldsymbol{\eta}_{0}\right)$}

Hoffmann and Stein (2008) stated that, the three particle fractions (dust feed, collected and emitted) were representing their masses by the symbols $\mathbf{M}_{\mathrm{f}}, \mathrm{M}_{\mathrm{c}}$ and $\mathrm{M}_{\mathrm{e}}$, respectively. The $\eta_{\mathrm{o}}$ is simply calculated as the mass fraction of the feed materials (dust) and collected by the cyclone:

$$
\eta_{o}=\frac{M_{C}}{M_{f}} \times 100=\left(1-\frac{M_{e}}{M_{f}}\right) \times 100=\frac{M_{C}}{M_{C}+M_{e}} \times 100
$$

\section{Statistical indicators}

Some statistical indicators were applied to compare and validate the measured with predicted results as illustrated in Table (5). In general, maximum value of $(\mathrm{r})$ indicates a better fit of the predicted model. On the other hand, the minimum values of (MRD, \%), (RSEP, \%) and (RMSE) were selected as a best fit model (Tantar et al., 2014). 
Table (5): Some statistical indicators to compare and validate the measured with predicted results

\begin{tabular}{|c|c|c|c|}
\hline $\begin{array}{l}\text { Statistical } \\
\text { Indicators }\end{array}$ & Equation & Reference & Remarks \\
\hline $\begin{array}{c}\text { mean relative } \\
\text { deviation } \\
\text { MRD, \% }\end{array}$ & $M R D(\%)=\left[\sum_{j=1}^{n} \frac{|x-y|}{x}\right] \times \frac{100}{n}$ & $\begin{array}{l}\text { Chen and } \\
\text { Morey (1989) }\end{array}$ & (21) \\
\hline $\begin{array}{c}\text { relative } \\
\text { standard error } \\
\text { of prediction } \\
R S E P, \%\end{array}$ & $\operatorname{RSEP}(\%)=100 \times \sqrt{\frac{\sum_{j=1}^{n}(x-y)^{2}}{\sum_{j=1}^{n} x^{2}}}$ & $\begin{array}{l}\text { Ghasemi and } \\
\text { Niazi }(2005)\end{array}$ & (22) \\
\hline $\begin{array}{l}\text { root mean } \\
\text { square error } \\
\quad R M S E\end{array}$ & $R M S E=\sqrt{\frac{\sum_{j=1}^{n}\left(x_{j}-y_{j}\right)^{2}}{n}}$ & $\begin{array}{l}\text { Jachner et al. } \\
\text { (2007) }\end{array}$ & (23) \\
\hline $\begin{array}{l}\text { Pearson } \\
\text { correlation } \\
\text { coefficient }(\mathrm{r})\end{array}$ & $r=\frac{n\left(\sum x y\right)-\left(\sum x\right)\left(\sum y\right)}{\sqrt{n \sum x^{2}-\left(\sum x\right)^{2}} \sqrt{n \sum y^{2}-\left(\sum y\right)^{2}}}$ & Spatz (2008) & (24) \\
\hline
\end{tabular}

\section{Measuring the Diameter of Emitted Dust}

In order to measure the diameter of emitted dust, microscopic slides and its coverslips were cleaned with $45 \%$ acetic acid and then dried in the oven for a few minutes at $40{ }^{\circ} \mathrm{C}$. The Haupt's adhesive according to (Yeung et al., 2015) was mounted on the slide and then exposed to the vortex finder against the air outlet stream to adhere the emitted dust. Then a drop of the Canada balsam (Sigma) was dropped carefully above the dust specimen and gently covered with a coverslip with slop angle of $45^{\circ}$ to avoid the presence of air bubbles. The slide was dried in the oven at 50 to $55^{\circ} \mathrm{C}$ about three weeks (Palma, 1978). The emitted dust was photographed using the Microscope (Leica, DM500). The diameter $(\mu \mathrm{m})$ of dust was measured by micrometer eyepiece slides.

\section{RESULTS AND DISCUSSION}

\section{Pressure Drop $(\Delta \mathbf{P})$}

The relationship between inlet air velocity and pressure drop under different cone heights is illustrated in Fig. (4). The maximum $\Delta \mathrm{P} 161.3$, 181.7 and $250.8 \mathrm{~Pa}$ were recorded at inlet air velocity of $20 \mathrm{~m} / \mathrm{s}$, cone heights of 30, 50 and $70 \mathrm{~cm}$ under vortex finder lengths of 40, 40 and 0 $\mathrm{cm}$ and dipleg lengths of 55, 25 and $25 \mathrm{~cm}$, respectively. Meanwhile the minimum $\Delta \mathrm{P}$ were $60.2,63,6$ and $80.6 \mathrm{~Pa}$ recorded at inlet air velocity of $14 \mathrm{~m} / \mathrm{s}$, cone heights of 30,50 and $70 \mathrm{~cm}$ under vortex finder lengths of 10,30 and $40 \mathrm{~cm}$ and dipleg lengths of 25,55 and $55 \mathrm{~cm}$, respectively. 


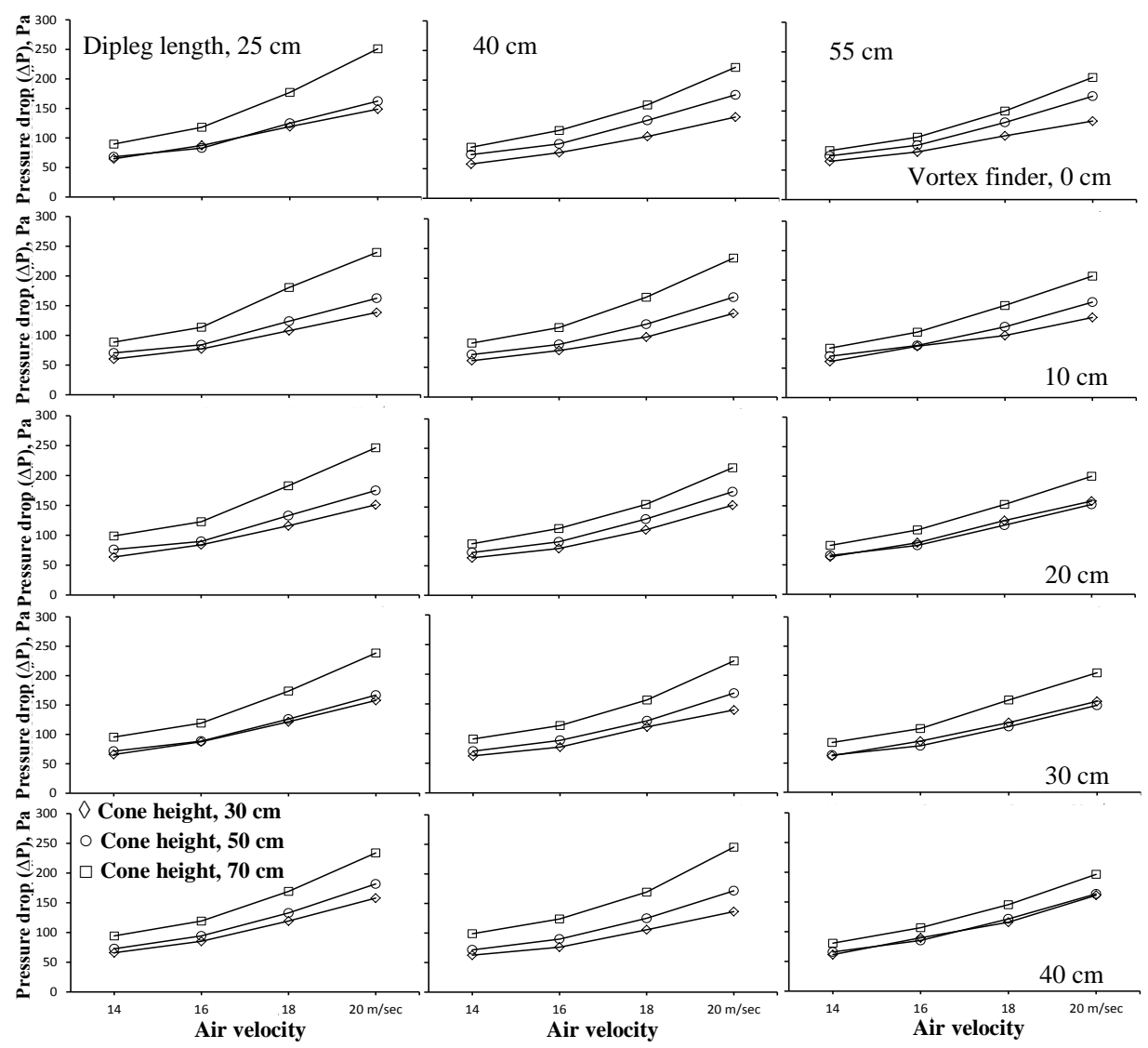

Fig. (4): Effect of inlet air velocity on measured pressure drop at different cone heights, vortex finder lengths and dipleg lengths

In general, the measured $\Delta \mathrm{P}$ increased with the increase of inlet air velocity and cone height; the obtained results were in agree with (Chuah et al., 2006 and Juengcharoensukying et al., 2017). Moreover, the results showed that, the pressure drop were increased with increasing cyclone size according to (Azadi et al., 2010) and the observed results showed that, also the effect of both vortex finder length and dipleg length on $\Delta \mathrm{P}$ had a tiny effect and neglected, these results were in agree with (Elsayed, 2011).

\section{Efficiency of Cyclone}

The main performance characteristics of the cyclone are $\eta_{o}$ and $\eta_{i}$. The factor affecting on $\eta_{\mathrm{o}}$ based on a design parameters number of effective 
turns $\left(\mathrm{N}_{\mathrm{e}}\right)$ in a cyclone, $l_{n}, l, \mathrm{~h}_{2}, \mathrm{~S}$ and $\mathrm{h}_{3}$ and factor based on operation parameters are $v_{i}, \Delta \mathrm{P}$ and $\mathrm{d}_{50}$ (Schnell \& Brown, 2002; Hoffmann \& Stein, 2008; Tan, 2008 and El-Batsh, 2013).

\section{Number of effective turns $\left(\mathrm{Ne}_{\mathrm{e}}\right)$}

The number of effective turns $\left(\mathrm{N}_{\mathrm{e}}\right)$ which calculated for three cone heights, according to Lapple model equation (3) is shown in Fig. (5).

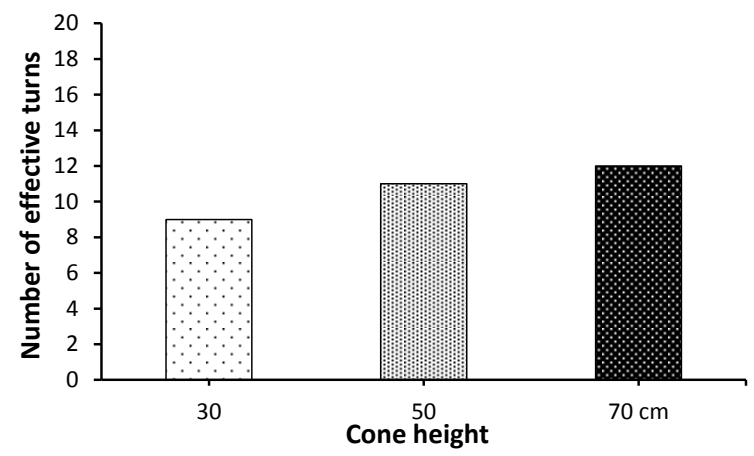

Fig. (5): Number of effective turns in the cyclone for three cone heights

As shown in the Fig. (5) the $\mathrm{N}_{\mathrm{e}}$ increased with increase the cone height. A more effective turns of the air stream result in a higher collection efficiency, according to (Lapple, 1950).

\section{Natural vortex length $\left(l_{n}\right)$ and physical length $(l)$}

The comparative of the results of $l_{n}$ were 60,50 and $30 \mathrm{~cm}$ according to (Alexander, 1949; Bryant et al., 1983 \& Ji et al., 1991), respectively. Table (6) illustrates the $l_{n}$ and $l$ at different cone heights and vortex finder lengths. The $l_{n}$ according to (Alexander, 1949) equal and longer than the $l$; were $60 \geq 60,50$ and $40 \mathrm{~cm}$ at vortex finder lengths of 20,30 and $40 \mathrm{~cm}$, respectively, at cyclone cone height of $30 \mathrm{~cm}$. While at cyclone cone height of $50 \mathrm{~cm}$ the $l_{n}$ equal the $l$ only at vortex finder length of 40 $\mathrm{cm}$. Meanwhile, at the cyclone cone height of $70 \mathrm{~cm}$ the $l_{n}$ lower than the $l$ at all vortex finder lengths. The good design when the $l_{n} \geq l$ and $\mathrm{H}_{t} / \mathrm{D}_{\mathrm{c}}$ ratios within 2-10 lead to high $\eta_{\mathrm{o}}$. At cone height of $30 \mathrm{~cm}$ the $l_{n} \geq l$ and the ratios were 2.6, 3.3 and 4 at cone heights of 30,50 and $70 \mathrm{~cm}$, respectively. These results are in agree with (Büttner, 1999). This means that when the $\mathrm{S}$ increase lead to decrease of $l$, increase $l_{n}$ and $\eta_{\mathrm{o}}$ at the same $\mathrm{H}_{\mathrm{t}}$. 
Table (6): The natural vortex length and physical length at different cone heights and vortex finder lengths according to (Alexander, 1949).

\begin{tabular}{|c|c|c|c|c|c|}
\hline \multicolumn{2}{|c|}{$\begin{array}{l}\text { Cone height, } \mathrm{cm} \\
\text { Total height, } \mathrm{cm}\end{array}$} & $\begin{array}{l}30 \\
80\end{array}$ & $\begin{array}{c}50 \\
100 \\
\end{array}$ & $\begin{array}{c}70 \\
120 \\
\end{array}$ & $\begin{array}{l}\text { Natural vortex } \\
\text { finder }\left(l_{n}\right), \mathrm{cm}\end{array}$ \\
\hline \multirow{6}{*}{ 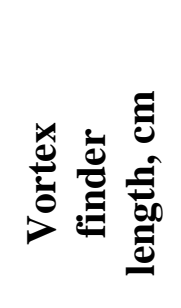 } & & \multicolumn{3}{|c|}{ Physical length $(l)$, cm } & \\
\hline & $\mathbf{0}$ & 80 & 100 & 120 & 60 \\
\hline & 10 & 70 & 90 & 110 & 60 \\
\hline & 20 & 60 & 80 & 100 & 60 \\
\hline & 30 & 50 & 70 & 90 & 60 \\
\hline & 40 & 40 & 60 & 80 & 60 \\
\hline
\end{tabular}

The selection of $\mathrm{S}$ was ideal in the cone height of $30 \mathrm{~cm}$, while in the cone heights of 50 and $70 \mathrm{~cm}$, it should be selected greater than $40 \mathrm{~cm}$. In general, higher $\eta_{\mathrm{o}}$ not only corresponds with increase $l_{n}$, but also with another variables such as the ratio between $\mathrm{H}_{t} / \mathrm{D}_{\mathrm{c}}, \mathrm{N}_{\mathrm{e}}, \mathrm{d}_{50}$ and $\Delta \mathrm{P}$.

\section{Measurement of overall collection efficiency}

The overall collection efficiency $\left(\eta_{\mathrm{o}}\right)$ is usually coined to refer the mass fraction of solid at the inlet of cyclone recovered in the gas stream at the end of the cyclone (dustbin) expressed in percentage.

Generally, $\eta_{\mathrm{o}}$ increased with increase inlet air velocity at different cone heights, dipleg lengths and vortex finder lengths. For instance, at cone height $30 \mathrm{~cm}$, dipleg length $25 \mathrm{~cm}$ and vortex finder length zero $\mathrm{cm} \eta_{\mathrm{o}}$ values were 95.34, 96.05, 96.11 and $96.99 \%$ at inlet air velocities of 14 , 16, 18 and $20 \mathrm{~m} / \mathrm{s}$, respectively as shown in Fig. (6).

The obtained results were in agreement with (Lapple, 1951b and Leith \& Licht, 1972), where increase inlet air velocity leads to decrease $\mathrm{d}_{50}$, which was inversely proportional to the $\eta_{\mathrm{o}}$. Otherwise $\eta_{\mathrm{o}}$ increased with increase cone height. For instance, under dipleg length $25 \mathrm{~cm}$, vortex finder length zero $\mathrm{cm}$ and the inlet air velocity $14 \mathrm{~m} / \mathrm{s} \eta_{\mathrm{o}}$ values were 95.34, 95.45 and $96.21 \%$ at cone heights of 30,50 and $70 \mathrm{~cm}$, respectively. The obtained results attributed to increase cone height that leads to decrease $\mathrm{d}_{50}$ and increase the $\mathrm{N}_{\mathrm{e}}$ and $l$ which caused increasing $\eta_{\mathrm{o}}$ according to (Lapple, 1950 and Büttner, 1999). 


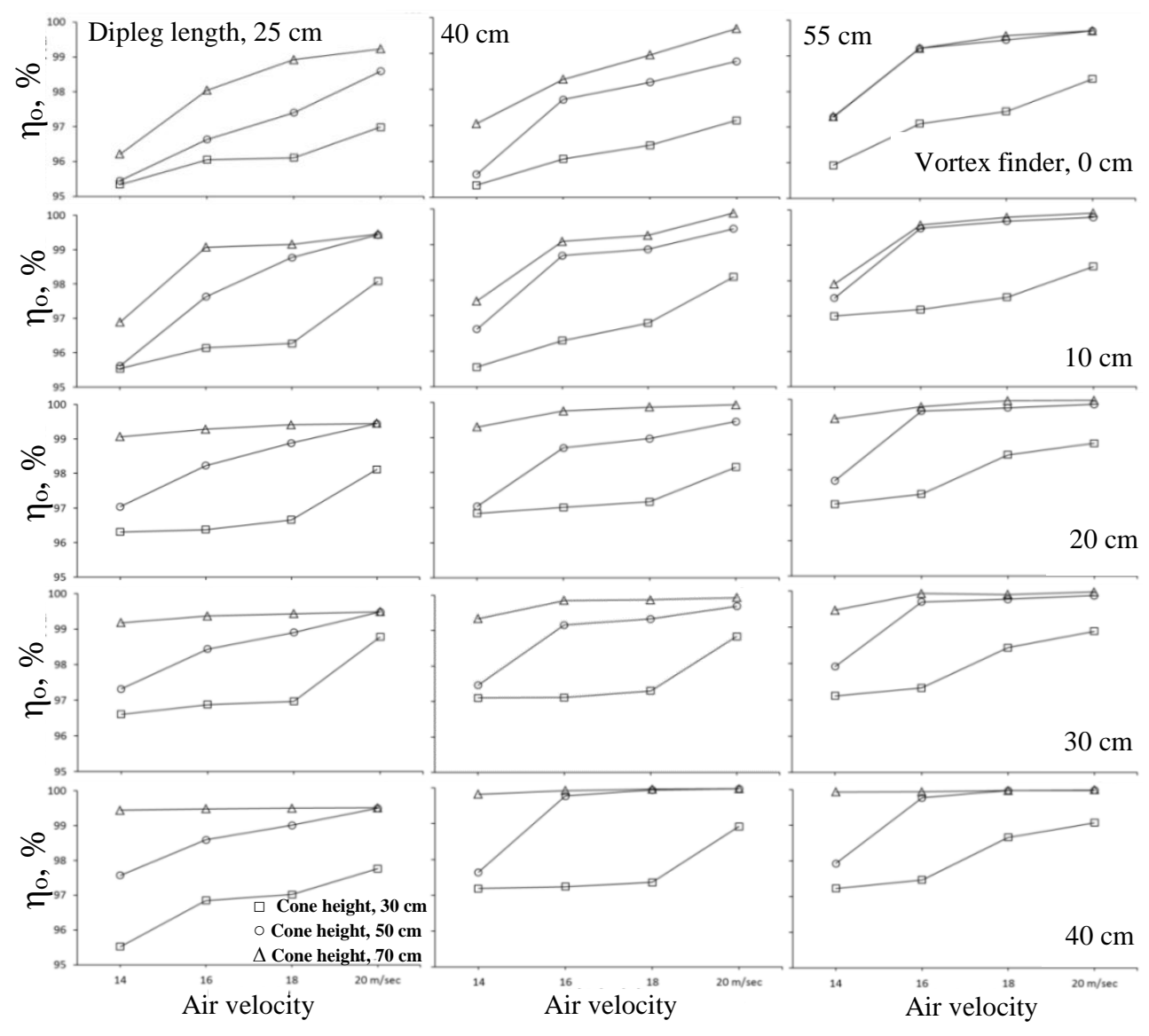

Fig. (6): The overall collection efficiency of coarse wheat bran under different inlet air velocities, cone heights, dipleg lengths and vortex finder lengths

Also in general, $\eta_{\mathrm{o}}$ increased with increase vortex finder length except at dipleg length of $25 \mathrm{~cm}$, cone height of $30 \mathrm{~cm}$ and inlet air velocity of 14 $\mathrm{m} / \mathrm{s} \eta_{\mathrm{o}}$ values were $95.34,95.54,96.31,96.61$ and $95.25 \%$ at vortex finder lengths of $0,10,20,30$ and $40 \mathrm{~cm}$, respectively. While, $\eta_{\mathrm{o}}$ at dipleg length of $40 \mathrm{~cm}$, cone height of $30 \mathrm{~cm}$ and inlet air velocity of 14 $\mathrm{m} / \mathrm{s}$ were $95.34,95.55,96.84,97.10$ and $97.19 \%$ at vortex finder lengths of $0,10,20,30$ and $40 \mathrm{~cm}$, respectively. This result may be due to increase the vortex finder length with shorter cone height leads to reach the outer vortex (spiral motion) to the dustbin, which causes particles reentrained into the vortex from the material already separated, thereby 
decrease $\eta_{\mathrm{o}}$ according to (Hoffmann \& Stein, 2008 and Qian et al., 2006). The $\eta_{\mathrm{o}}$ can be improved significantly by changing the dust outlet geometry and cone height according to (Obermair et al., 2003). To avoid this phenomena in case coarse wheat bran, the cone height should be more than $30 \mathrm{~cm}$ or dipleg length more than $25 \mathrm{~cm}$. In addition, $\eta_{\mathrm{o}}$ increased with increase dipleg length. For instance, under cone height 30 $\mathrm{cm}$, inlet air velocity $14 \mathrm{~m} / \mathrm{s}$ and vortex finder length zero $\mathrm{cm}, \eta_{\mathrm{o}}$ were $95.34,95.34$ and $95.93 \%$ at dipleg length 25,40 and $55 \mathrm{~cm}$, respectively. The minimum value of $\eta_{\mathrm{o}}$ was $95.34 \%$ at minimum inlet air velocity $14 \mathrm{~m} / \mathrm{s}$, cone height $30 \mathrm{~cm}$, vortex finder length zero $\mathrm{cm}$ and dipleg length $25 \mathrm{~cm}$, while the maximum value was $99.99 \%$ at maximum inlet air velocity $20 \mathrm{~m} / \mathrm{s}$, cone height $70 \mathrm{~cm}$, vortex finder length $40 \mathrm{~cm}$ and dipleg length $55 \mathrm{~cm}$. On the other hand, the maximum and minimum predicted $\mathrm{d}_{50}$ of coarse wheat bran for Hoffmann \& Stein and Lapple models were 56 and $23 \mu \mathrm{m}$ at minimum and maximum of the measured $\eta_{\mathrm{o}}$, respectively, these results were in agree with (Lapple, 1951b and Leith \& Licht, 1972). Furthermore, the coarse wheat bran diameter, which emitted was equal or less than $10 \mu \mathrm{m}$ as shown in Fig. (7) and less than predicted of $d_{50}$ at maximum $\eta_{0}$. These results was in complete agreement with those obtained from Cooper and Alley (2002), which found that, the cyclones can reach efficiencies exceeding $99 \%$ for particles larger than $5 \mu \mathrm{m}$.

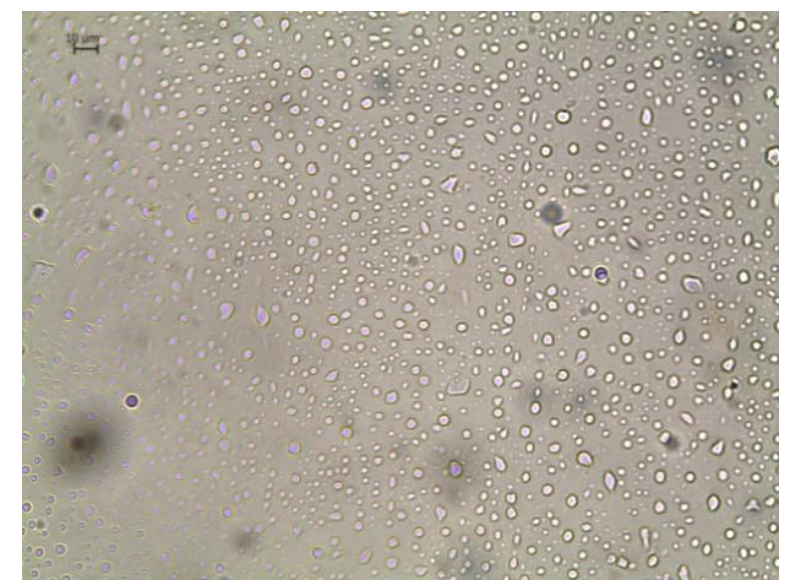

Fig. (7): The photographed emitted particles of coarse wheat bran using microscope (Leica, DM500) 


\section{Calculating the cut-off diameter (d50)}

Four models were used to calculate the $\mathrm{d}_{50}$ according to (Lapple, 1950; Rietema, 1959; Iozia \& Leith, 1990 and Hoffmann \& Stein, 2008) due to the design of cyclone inlet was rectangular shape. Figure (8) displays the $\mathrm{d}_{50}$ of coarse wheat bran according to aforementioned four models at dipleg length of $25 \mathrm{~cm}$.

The $\mathrm{d}_{50}$ was decreased with increase inlet air velocity at four models. The $\mathrm{d}_{50}$ was not affected by dipleg length, except Rietema model. The Hoffmann \& Stein model was corresponding with radial velocity at the control surface $\left(\mathrm{v}_{\mathrm{rcs}}\right)$, which depended on the vortex finder length as aforementioned in equation (9). The $\mathrm{d}_{50}$ decreased with increase vortex finder length, for instance at inlet air velocity $14 \mathrm{~m} / \mathrm{s}$ and cone height $30 \mathrm{~cm}$ the $\mathrm{d}_{50}$ values were $56.42,54.34,52.24,50.17$ and $48.24 \mu \mathrm{m}$ at vortex finder lengths of $0,10,20,30$ and $40 \mathrm{~cm}$, respectively under dipleg length of $25 \mathrm{~cm}$.

Meanwhile the $\mathrm{d}_{50}$ in this model increased with increase cone height. For instance, at inlet air velocity of $14 \mathrm{~m} / \mathrm{s}$ and vortex finder length of zero $\mathrm{cm}$; the $\mathrm{d}_{50}$ values were $56.42,60.22$ and $63.86 \mu \mathrm{m}$ at cone heights of 30,50 and $70 \mathrm{~cm}$, respectively. The Iozia \& Leith model was reverse Hoffmann \& Stein model, on other words, the $\mathrm{d}_{50}$ increased with increase vortex finder length and decreased with increase cone height.

The calculation of Iozia \& Leith model depends on the height of the control surface $\left(\mathrm{H}_{\mathrm{cs}}\right)$. When $\mathrm{H}_{\mathrm{cs}}$ increase, lead to decrease the $\mathrm{d}_{50}$ and vice versa as aforementioned in equation (5). For instance, at inlet air velocity of $14 \mathrm{~m} / \mathrm{s}$ and cone height of $30 \mathrm{~cm}$ the $\mathrm{d}_{50}$ values were $8.25,8.82,9.53$, 10.44 and $11.67 \mu \mathrm{m}$ at vortex finder lengths of $0,10,20,30$ and $40 \mathrm{~cm}$, respectively under dipleg length of $25 \mathrm{~cm}$. Meanwhile, the $\mathrm{d}_{50}$ values at inlet air velocity of $14 \mathrm{~m} / \mathrm{s}$ and vortex finder length of zero $\mathrm{cm}$ were 8.25 , 7.95 and $7.70 \mu \mathrm{m}$ at cone heights of 30,50 and $70 \mathrm{~cm}$, respectively. The Rietema model resulted in the lowest value of $d_{50}$ compared to the other three models; the model depends on design and operation parameters via $\mathrm{H}_{\mathrm{t}}$ and $\Delta \mathrm{P}$, respectively as aforementioned in equation (4). In other words, increase the inlet air velocity, $\mathrm{H}_{\mathrm{t}}$ and $\Delta \mathrm{P}$ lead to decrease the $\mathrm{d}_{50}$. For instance, at vortex finder length of zero $\mathrm{cm}$ and cone height of $30 \mathrm{~cm}$ at inlet air velocities of $14,16,18$ and $20 \mathrm{~m} / \mathrm{s}$ at $\Delta \mathrm{P} 64.73,87.45,119.24$ 
and $148.77 \mathrm{~Pa}$ the $\mathrm{d}_{50}$ were $3.13,2.88,2.62$ and $2.47 \mu \mathrm{m}$, respectively under dipleg length $25 \mathrm{~cm}$.

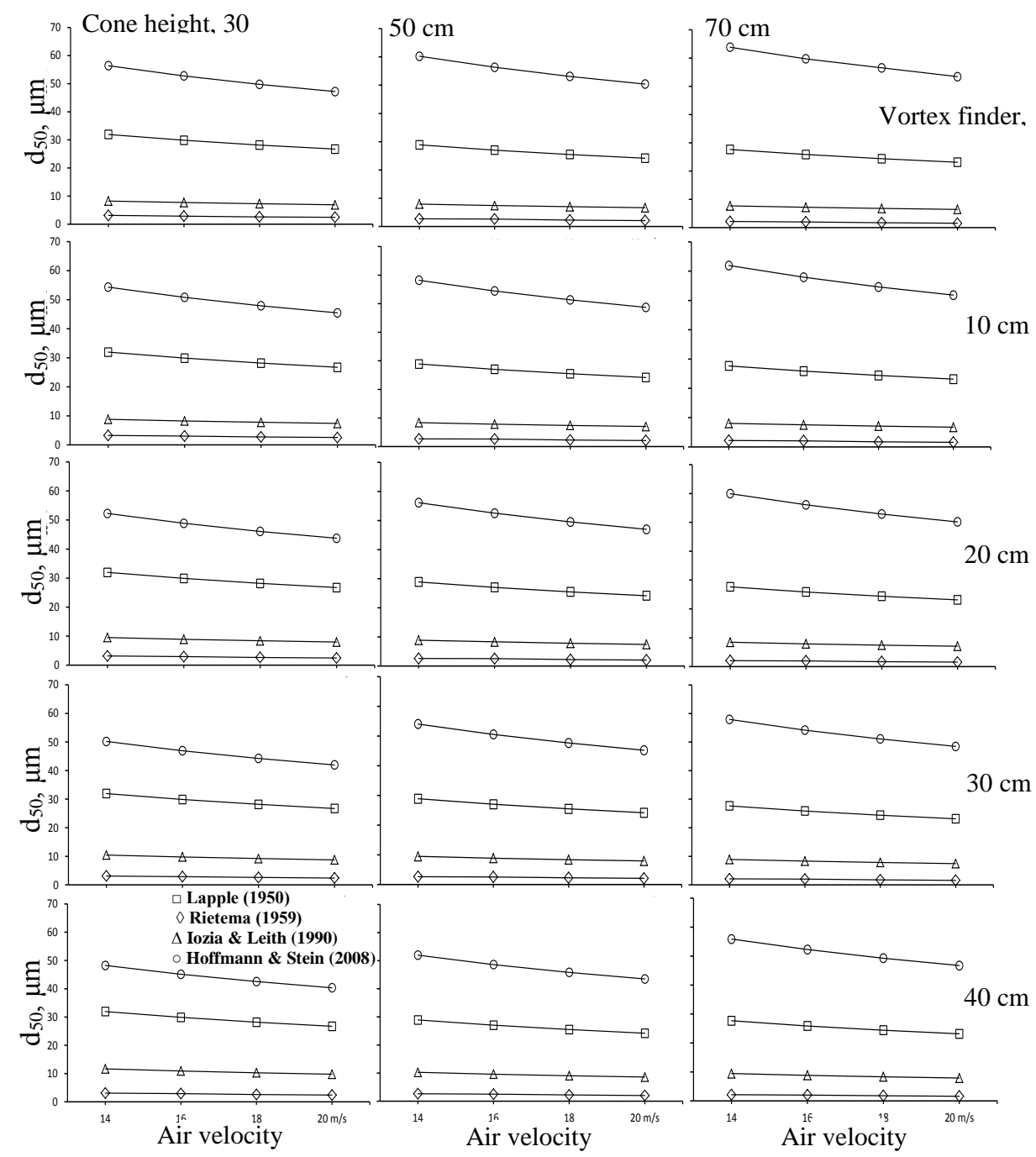

Fig. (8): The relationship between inlet air velocity and the dso of coarse wheat bran at different cone heights and vortex finder lengths at dipleg length $25 \mathrm{~cm}$

Meanwhile, at inlet air velocity of $14 \mathrm{~m} / \mathrm{s}$ and vortex finder length of zero $\mathrm{cm}$ at $\Delta \mathrm{P} 64.73,68.14$ and $89.72 \mathrm{~Pa}$ the $\mathrm{d}_{50}$ were $3.13,2.73$ and $2.17 \mu \mathrm{m}$ at cone heights of 30,50 and $70 \mathrm{~cm}$, respectively. Most conventional ways for determining the predicted $\eta_{\mathrm{o}}$ of cyclone is by determining the 
$\mathrm{d}_{50}$ of particle that needs to be separated. The $\mathrm{d}_{50}$ is inversely proportional to the $\eta_{\mathrm{o}}$ otherwise decreasing $d_{50}$ leads to increase $\eta_{\mathrm{o}}$ (Lapple, 1951 b and Leith and Licht, 1972).

\section{Predicted overall collection efficiency}

In order to predict the $\eta_{\mathrm{o}}$ in cyclones based on equation (13) according to (Lapple, 1951a), which was used before to calculate cut-off diameter $\mathrm{d}_{50}$. Figure (9) and the results were illustrated comparison between the predicted and measured $\eta_{\mathrm{o}}$ of coarse wheat bran at different inlet air velocities, cone heights and vortex finder lengths under dipleg length 55 $\mathrm{cm}$ which was the best dipleg for measured of $\eta_{\mathrm{o}}$.

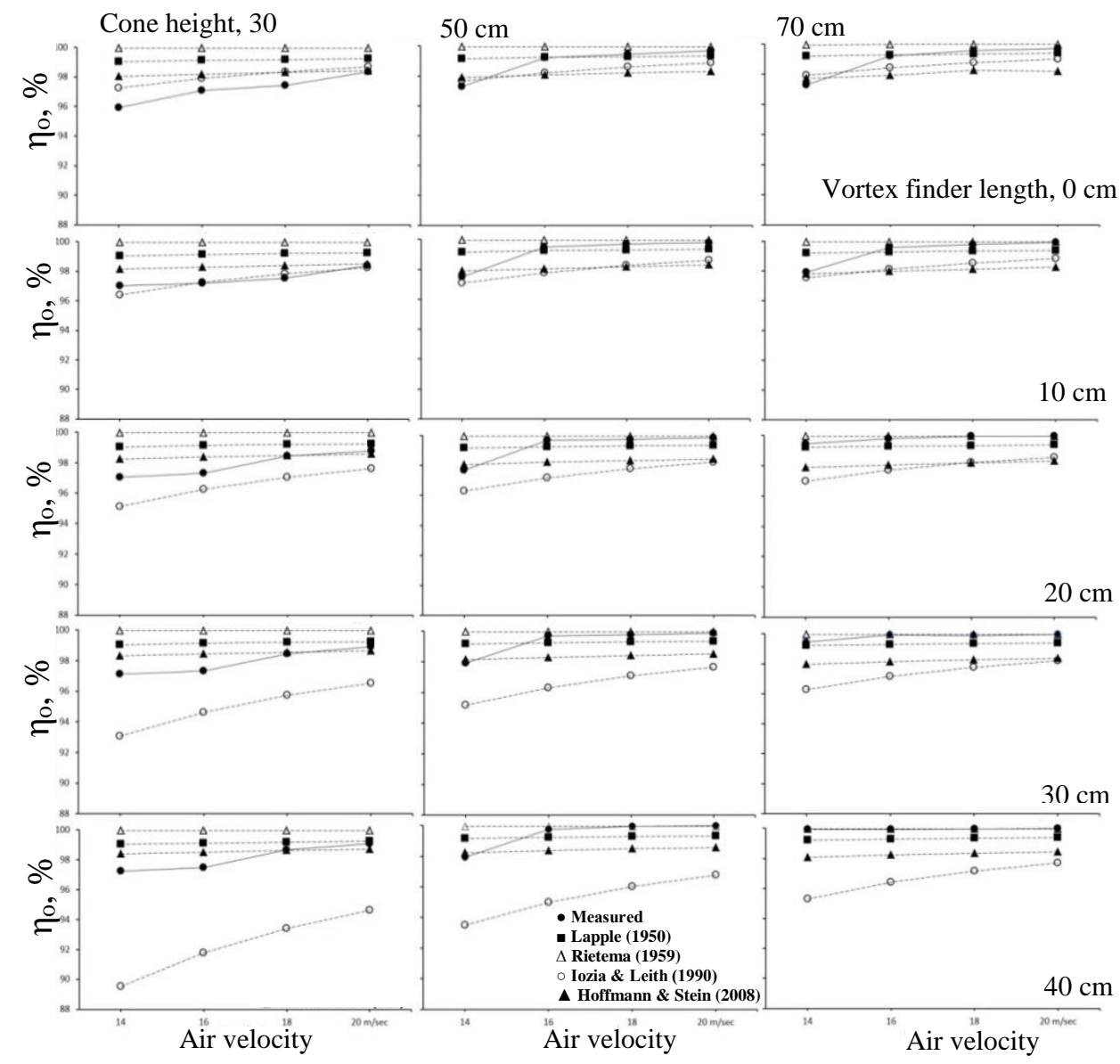

Fig. (9): Comparison between the predicted and measured of overall collection efficiency of coarse wheat bran at different inlet air velocities, cone heights and vortex finder lengths under dipleg length $55 \mathrm{~cm}$ 
In general, in Rietema model the predicted $\eta_{\mathrm{o}}$ had the highest values and it was constant at different inlet air velocities, vortex finder lengths and cone heights comparing with other models. while in Iozia \& Leith model the predicted $\eta_{0}$ was increased with increase inlet air velocity and cone heights and decreased with increase vortex finder length. In case Lapple and Hoffmann \& Stein models the predicted $\eta_{\mathrm{o}}$ had neglected increase at different inlet air velocities, vortex finder lengths and cone heights.

The results of models were compared to the measured values, which determined by weight method. To assess the predictive validity of the models in comparison to the measured $\eta_{\mathrm{o}}$ to find out the best model under different parameters. Table (7) shows some statistical indicators for empirical models to validate predicted with measured values of $\eta_{\mathrm{o}}$.

Table (7): Some statistical indicators to validate predicted with measured values of overall collection efficiency of coarse wheat bran.

\begin{tabular}{|c|c|c|c|c|c|c|}
\hline \multicolumn{2}{|c|}{ Statistics parameters } & $\begin{array}{c}\text { Measured } \\
\text { values }\end{array}$ & Lapple & Rietema & $\begin{array}{c}\text { Iozia } \\
\text { \& Leith }\end{array}$ & $\begin{array}{c}\text { Hoffman \& } \\
\text { Stein }\end{array}$ \\
\hline \multirow{6}{*}{ 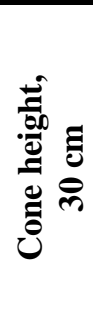 } & Mean & 97.18 & 99.15 & 99.95 & 95.87 & 98.41 \\
\hline & $\begin{array}{l}\text { Std. } \\
\text { deviation }\end{array}$ & 0.972 & 0.07908 & 0.00645 & 2.38048 & 0.17135 \\
\hline & $\mathbf{r}$ & - & 0.69775 & 0.01406 & 0.01994 & 0.78941 \\
\hline & MRD, \% & - & 2.036 & 2.859 & 2.240 & 1.316 \\
\hline & RSEP, \% & - & 2.233 & 3.017 & 2.937 & 1.526 \\
\hline & RMSE & - & 2.171 & 2.932 & 2.854 & 1.483 \\
\hline \multirow{6}{*}{ 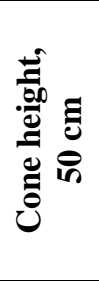 } & Mean & 98.60 & 99.26 & 99.95 & 97.10 & 98.25 \\
\hline & $\begin{array}{l}\text { Std. } \\
\text { deviation }\end{array}$ & 1.20858 & 0.07144 & 0.00360 & 1.36547 & 0.18819 \\
\hline & $\mathbf{r}$ & - & 0.74380 & 0.61079 & 0.14225 & 0.78772 \\
\hline & MRD, \% & - & 0.986 & 1.384 & 1.910 & 0.994 \\
\hline & RSEP, \% & - & 1.342 & 1.830 & 2.281 & 1.130 \\
\hline & RMSE & - & 1.323 & 1.804 & 2.250 & 1.114 \\
\hline \multirow{6}{*}{ 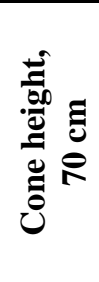 } & Mean & 99.30 & 99.30 & 99.95 & 97.73 & 98.13 \\
\hline & $\begin{array}{l}\text { Std. } \\
\text { deviation }\end{array}$ & 0.84734 & 0.06472 & 0.00446 & 0.93900 & 0.19182 \\
\hline & $\mathbf{R}$ & - & 0.52966 & 0.44890 & 0.08579 & 0.75047 \\
\hline & MRD, \% & - & 0.557 & 0.672 & 1.728 & 1.310 \\
\hline & RSEP, \% & - & 0.813 & 1.074 & 2.056 & 1.378 \\
\hline & RMSE & - & 0.808 & 1.066 & 2.042 & 1.369 \\
\hline
\end{tabular}


As shown in Table (7), the Rietema and Iozia \& Leith models were given an extreme result at different cone heights compared with measured of $\eta_{\mathrm{o}}$ because it had the lowest values of Pearson correlation coefficient (r) and at the same time had the highest values of (MRD, \%), (RSEP, \%) and (RMSE).

The Hoffmann \& Stein model was more validation to predict $\eta_{\mathrm{o}}$ due to that the model had the highest values of (r) and at the same time had the lowest values of (MRD, \%), (RSEP, \%) and (RMSE) at cone heights of 30 and $50 \mathrm{~cm}$. On the other hand, the Hoffmann \& Stein model at cone heights of 30 and $50 \mathrm{~cm}$ was the best model to predict $\eta_{\mathrm{o}}$, which the mean were 98.41 and $98.25 \%$ and closed with the mean of measured $\eta_{\mathrm{o}}$ 97.18 and $98.60 \%$, respectively. While Lapple model was more validation at cone height $70 \mathrm{~cm}$ due to that, the model had the highest values of (r) and at the same time had the lowest values of (MRD, \%), (RSEP, \%) and (RMSE). Thereby, the Lapple model was the best model to predict $\eta_{\mathrm{o}}$ at cone height $70 \mathrm{~cm}$ because had the same value of the mean measured $\eta_{0} 99.30 \%$. These results may be attributed to that, the predicted $\mathrm{d}_{50}$ at cone heights 30 and $50 \mathrm{~cm}$ of Hoffmann \& Stein model meet with the requirements of the predicted $\eta_{\mathrm{o}}$, on the other hand, Lapple model meet the requirements of the predicted $\eta_{\mathrm{o}}$ at cone height $70 \mathrm{~cm}$ as illustrated in Table (8).

Table (8): Comparison between the mean of the overall collection efficiency and cut-off diameter for measured and predicted models of coarse wheat bran at different cone heights.

\begin{tabular}{|c|c|c|c|c|c|}
\hline \multirow[t]{2}{*}{$\begin{array}{c}\text { Cone height, } \\
\mathrm{cm}\end{array}$} & \multirow{2}{*}{$\begin{array}{c}\text { Measured } \\
\eta_{0}, \%\end{array}$} & \multicolumn{2}{|c|}{$\begin{array}{c}\text { Hoffmann \& Stein } \\
\text { model }\end{array}$} & \multicolumn{2}{|c|}{$\begin{array}{c}\text { Lapple } \\
\text { model }\end{array}$} \\
\hline & & $\eta_{0}, \%$ & $\mathrm{~d}_{50}, \mu \mathrm{m}$ & $\eta_{0}, \%$ & $\mathrm{~d}_{50}, \mu \mathrm{m}$ \\
\hline 30 & 97.18 & 98.41 & 47.76 & 99.15 & 29.18 \\
\hline 50 & 98.60 & 98.26 & 51.3 & 99.26 & 26.40 \\
\hline 70 & 99.30 & 98.13 & 54.9 & 99.30 & 25.27 \\
\hline
\end{tabular}

\section{Optimum Design and Operating Parameters}

The $\eta_{\mathrm{o}}$ and $\Delta \mathrm{P}$ are the two most important parameters for determining the design and performance of a cyclone separator; these parameters are intimately related and affected by each other. In order to determine the optimum $\eta_{\mathrm{o}}$ must be a balance between the economics of 
operation, maintenance and the price of the separated material; in other words tradeoff between higher $\eta_{\mathrm{o}}$ and low $\Delta \mathrm{P}$ across the cyclone is essential according to (Dirgo \& Leith, 1985 and Demir et al., 2016). The maximum $\eta_{0}$ and minimum $\Delta P$ were observed as aforementioned under the influence of air velocity, cone height, vortex finder length, dipleg length and the interaction between them.
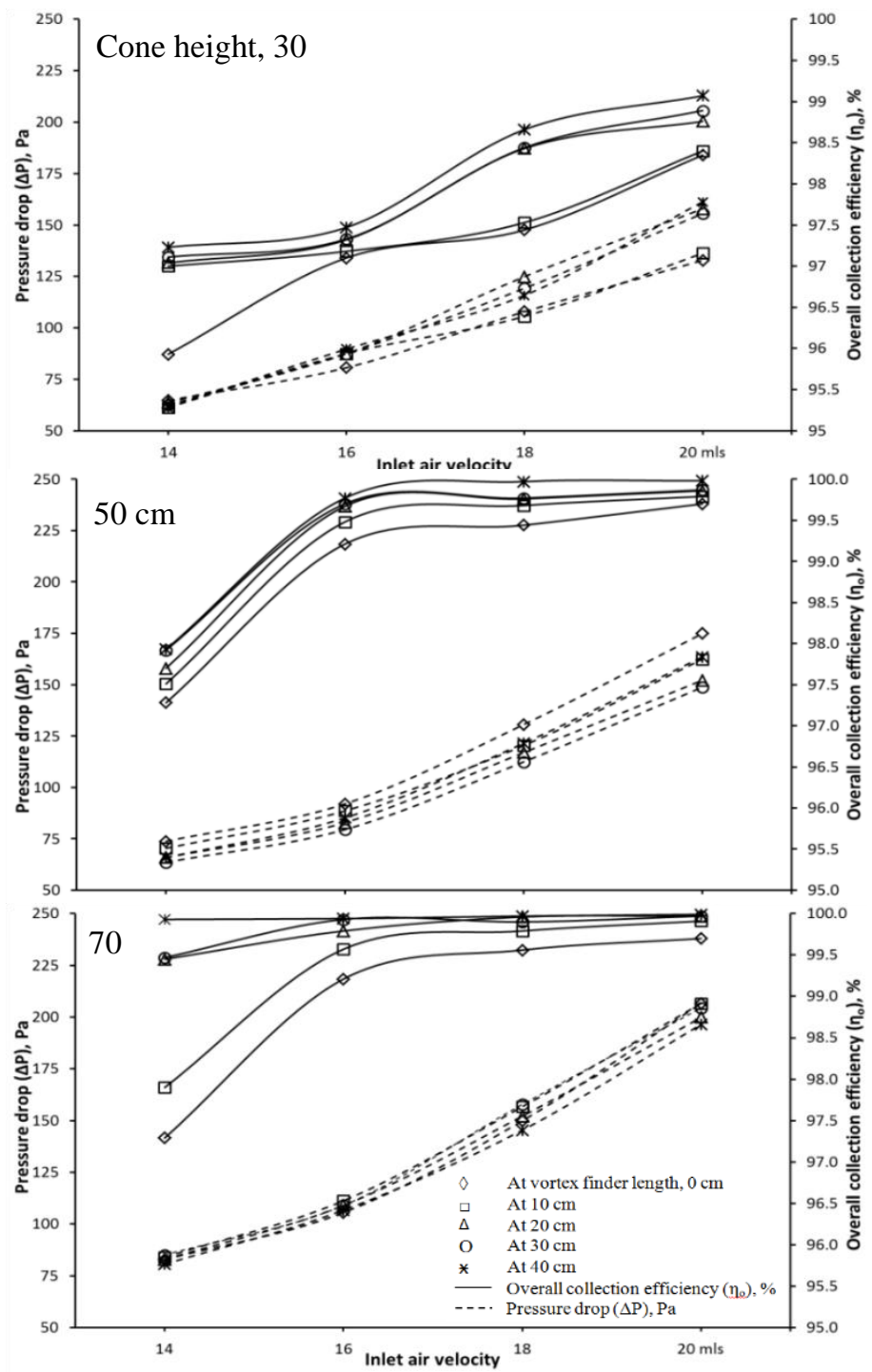

Fig. (10): Relationship between the measured overall collection efficiency and pressure drops of coarse wheat bran at different inlet air velocities, cone heights and vortex finder lengths under dipleg length $55 \mathrm{~cm}$ 
As aforementioned the maximum measured $\eta_{\mathrm{o}}$ for coarse wheat bran was at cone height of $70 \mathrm{~cm}$ under dipleg length of $55 \mathrm{~cm}$. As shown in Fig. (10), in cone height of $70 \mathrm{~cm}$, the highest values of $\eta_{\mathrm{o}}$, which were approximately constant ranged from 99.93 to $99.99 \%$ obtained at vortex finder length $40 \mathrm{~cm}$ with inlet velocities from 14 to $20 \mathrm{~m} / \mathrm{s}$ and the same time $\Delta \mathrm{P}$ were increased rapidly from 80.63 to $196.47 \mathrm{~Pa}$, respectively. These results are in agree with those obtained by Pandya (2010), which found that the increase in inlet air velocity lead to increase $\eta_{\mathrm{o}}$, rapidly increase $\Delta \mathrm{P}$ and increases the manufacturing cost.

So that it is preferable to select the minimum inlet air velocity, which leads to minimum $\Delta \mathrm{P}$ in order to decrease operating and maintenance costs. in other words, at cone height of $70 \mathrm{~cm}$ the optimum operating and design parameters were inlet air velocity of $14 \mathrm{~m} / \mathrm{s}$ and vortex finder length of $40 \mathrm{~cm}$, respectively. While, at vortex finder lengths of 30 and 20 or $10 \mathrm{~cm}$, the optimum inlet air velocity were $16 \mathrm{~m} / \mathrm{s}$ and $18 \mathrm{~m} / \mathrm{s}$, respectively. The vortex finder length zero $\mathrm{cm}$ had the minimum $\eta_{\mathrm{o}}$ and maximum $\Delta \mathrm{P}$ and not preferred. At cone height $50 \mathrm{~cm}$ the maximum $\eta_{\mathrm{o}}$ were 99.97 and $99.98 \%$ and $\Delta \mathrm{P} 121.52$ and $163.53 \mathrm{~Pa}$ at inlet air velocities 18 and $20 \mathrm{~m} / \mathrm{s}$, respectively under vortex finder length $40 \mathrm{~cm}$. These results are in agreement with those obtained from Shepherd and Lapple (1939), which found that the optimum operating velocity is around $15-30 \mathrm{~m} / \mathrm{s}$. While, in vortex finder lengths of 10,20 and $30 \mathrm{~cm}$, the $\eta_{\mathrm{o}}$ were $99.79,99.86$ and $99.87 \%$ and $\Delta \mathrm{P} 162.40,152.18$ and $148.77 \mathrm{~Pa}$, respectively, at inlet air velocity of $20 \mathrm{~m} / \mathrm{s}$; on other words, the suitable parameters were $30 \mathrm{~cm}$ vortex finder length and inlet air velocity of $20 \mathrm{~m} / \mathrm{s}$. Meanwhile, vortex finder length of zero $\mathrm{cm}$ was not preferred at cone height of $50 \mathrm{~cm}$. Meanwhile, the cone height of $30 \mathrm{~cm}$ was undesirable because it has low $\eta_{\mathrm{o}}$ and high $\Delta \mathrm{P}$.

\section{CONCLUSIONS}

The study carried out to evaluate the performance of local fabricated cyclone based on optimal operating and design conditions to obtain the highest overall collection efficiency $\left(\eta_{\mathrm{o}}\right)$ and the lowest operating pressure drop $(\Delta \mathrm{P})$ for separating coarse wheat bran. Moreover, some mathematical models were used to predict $\eta_{\mathrm{o}}$ and some statistical indicators for comparison and validation with measured results. 


\section{The experimental results were addressed as the following:}

- The measured $\eta_{\mathrm{o}}$ and $\Delta \mathrm{P}$ increase with increase inlet air velocity and cone height. The minimum $\Delta \mathrm{P}$ was $60.2 \mathrm{~Pa}$ at inlet air velocity of $14 \mathrm{~m} / \mathrm{s}$ and cone height of $30 \mathrm{~cm}$, meanwhile, the maximum $\Delta \mathrm{P}$ was $250.8 \mathrm{~Pa}$ at inlet air velocity of $20 \mathrm{~m} / \mathrm{s}$ and cone height of $70 \mathrm{~cm}$.

- The number of effective turns increased with increase the cone height, they were 9, 11 and 12 at cone heights of 30,50 and $70 \mathrm{~cm}$, respectively and it is reflected on increasing the $\eta_{\mathrm{o}}$. Moreover, decreasing $\mathrm{d}_{50}$ with increase inlet air velocity lead to increase $\eta_{\mathrm{o}}$ at different cone heights, dipleg lengths and vortex finder lengths; for instance, at cone height of $30 \mathrm{~cm}$ the $\mathrm{d}_{50}$ of Lapple model were 31.95, $29.88,28.17$ and $26.73 \mu \mathrm{m}$ for coarse wheat bran at inlet air velocities of $14,16,18$ and $20 \mathrm{~m} / \mathrm{s}$, respectively, while, the mean of measured $\eta_{\mathrm{o}}$ were $96.38,96.83,97.24$ and $98.29 \%$, respectively.

- The minimum value of the measured $\eta_{0}$ coarse wheat bran was $95.34 \%$ at minimum inlet air velocity of $14 \mathrm{~m} / \mathrm{s}$, cone height of $30 \mathrm{~cm}$, vortex finder length of zero cm, dipleg length of $25 \mathrm{~cm}$ and predicted $\mathrm{d}_{50} 56 \mu \mathrm{m}$ for Hoffmann \& Stein model (more validation at cone height of $30 \mathrm{~cm}$ ), while, the maximum value was $99.99 \%$ at maximum inlet air velocity of $20 \mathrm{~m} / \mathrm{s}$, cone height of $70 \mathrm{~cm}$, vortex finder length of $40 \mathrm{~cm}$, dipleg length of $55 \mathrm{~cm}$ and predicted $\mathrm{d}_{50}$ $23 \mu \mathrm{m}$ for Lapple model (more validation at cone height of $70 \mathrm{~cm}$ ).

- The diameter of coarse wheat bran which emitted was equal or less than $10 \mu \mathrm{m}$ and the same time less than predicted of $\mathrm{d}_{50}$ at maximum $\eta_{\mathrm{o}}$. On other word, all the diameters more than $10 \mu \mathrm{m}$ were captured and separated in the cyclone.

- The Hoffmann \& Stein model was the best model and more validation to predict $\eta_{0}$ of coarse wheat bran at cone height of 30 and $50 \mathrm{~cm}$, which the mean were 98.41 and $98.25 \%$ and closed with the mean of measured $\eta_{0} 97.18$ and $98.60 \%$, respectively. The Lapple model was the best model and more validation to predict $\eta_{\mathrm{o}}$ of coarse wheat bran at cone height of $70 \mathrm{~cm}$ because had the same value of mean measured $\eta_{\mathrm{o}} 99.30 \%$.

- The optimum operating and design parameters at cone height of $70 \mathrm{~cm}$ were inlet air velocity of $14 \mathrm{~m} / \mathrm{s}$ and vortex finder length of $40 \mathrm{~cm}$, 
which lead to high $\eta_{\mathrm{o}} 99.93 \%$ and low $\Delta \mathrm{P} 80.63 \mathrm{~Pa}$. While, at cone height of $50 \mathrm{~cm}$ the optimum operating and design parameters were at inlet air velocity of $18 \mathrm{~m} / \mathrm{s}$ under vortex finder length of $40 \mathrm{~cm}$ which lead to high $\eta_{\mathrm{o}} 99.97 \%$ and low $\Delta \mathrm{P} 121.52 \mathrm{~Pa}$. Meanwhile, the cone height of $30 \mathrm{~cm}$ was undesirable because it has low $\eta_{\mathrm{o}}$ and high $\Delta \mathrm{P}$.

- The vortex finder length of zero $\mathrm{cm}$ had the minimum $\eta_{\mathrm{o}}$ and maximum $\Delta \mathrm{P}$ and not preferred at all cone heights.

\section{REFERENCES}

Abdel-Hadi, M. A. (2014): Effect of cyclone inlet velocity and vortex finder height on coarse wheat bran dust separation. Misr J. Ag. Eng., 31(3): 1001-1024.

Alexander, R. M. (1949): Fundamentals of cyclone design and operation. Proceedings of the Australian Institute of Minerals and Metals (New Series), 152/153: 202-228.

Appel, W. B. (1985): Physical properties of feed ingredients. In Feed Munufuczuring Technology III. $2^{\text {nd }}$ Ed., (R.R. McEllhiney, ed.) pp. 557-562, Am. Feed Ind. Assoc., Arlington, VA. USA.

Azadi M.; M. Azadi and A. Mohebbi (2010): A CFD study of the effect of cyclone size on its performance parameters. Journal of Hazardous Materials, 182(1-3): 835-841.

Bryant, H. S.; R. W. Silverman and F. A. Zenz (1983): How dust in gas affects cyclone pressure drop. Hydrocarbon Processing, 62(4): 87-90.

Büttner, H. (1999): Dimensionless representation of particle separation characteristic of cyclones. Journal of Aerosol Science, 30(10): 1291-1302.

Chen, C. C. and R. V. Morey (1989): Comparison of four EMC/ERH equations. Trans. Amer. Soc. Agr. Eng., 32: 983-989.

Chen, J. and M. Shi (2007): A universal model to calculate cyclone pressure drop. Powder Technology, (171): 184-191.

Chuah, T. G.; J. Gimbun and T. S. Y. Choong (2006): A CFD study of the effect of cone dimensions on sampling aerocyclones performance and hydrodynamics. Powder Technology, 162: 126132. 


\section{Chuah, T. G.; J. Gimbun; T. S. Y. Choong and A. Fakhru'l-razi} (2003): Numerical prediction of cyclone pressure drop. Journal of Chemical Engineering and Environment, 2(2): 67-71.

Cooper, C. D. and F. C. Alley (2002): Air Pollution Control, A Design Approach, 3rd ed. Prospect Heights, Ill.: Waveland.

Cortés, C. and A. Gil (2007): Modeling the gas and particle flow inside cyclone separators. Progress in Energy and Combustion Science, 33(5): 409-452.

Demir, S.; A. Karadeniz and M. Aksel (2016): Effects of cylindrical and conical heights on pressure and velocity fields in cyclones. Powder Technology, 295: 209-217.

Dirgo, J., and D. Leith (1985): Performance of theoretically optimised cyclones. Filtration \& Separation, 22: 119-125.

El-Batsh, H. M. (2013): Improving cyclone performance by proper selection of the exit pipe. Applied Mathematical Modelling, 37: 5286-5303.

Elsayed, K. (2011): Analysis and optimization of cyclone separators geometry using RANS and LES methodologies. Ph.D. Thesis, Department of Mechanical Engineering, Faculty of Engineering, Vrije University. Brussel, Belgium.

Elsayed, K. and C. Lacor (2009): Investigation of the geometrical parameters effects on the performance and the flow-field of cyclone separators using mathematical models and large eddy simulation. $13^{\text {th }}$ Aerospace Sciences \& Aviation Technology (ASAT-13), Military Technical College, Cairo, Egypt.

Ghasemi, J. and A. Niazi (2005): Tow- and three- way chemometrics methods applied for spectrophotometric determination of lorazepam in pharmaceutical formulations and biological fluids. Analytic Chimica Acta, 533: 169-177.

Hoffmann, A. C., and L. E. Stein (2008): Gas cyclones and swirl tubes: principles, design and operation. ISBN 978-3-540-74694. $22^{\text {nd }}$ Edition, Springer Berlin Heidelberg, Germany.

Iozia, D. L. and D. Leith (1990): The logistic function and cyclone fractional efficiency. Aerosol Science and Technology, 12(3): 598-606. 
Jachner, S.; K. G. van den Boogaart and T. Petzoldt (2007): Statistical methods for the qualitative assessment of dynamic models with time delay (R Package qualV). Journal of Statistical Software, 22(8): 1-30.

Ji, Z. L.; X. L. Wu and M. X. Shi (1991): Experimental research on the natural turning length in the cyclone. Proceedings of Filtech Europa 91 Conference, Karlsruhe, Germany, 2: 583-589.

Juengcharoensukying, J.; K. Poochinda and B. Chalermsinsuwan (2017): Effects of cyclone vortex finder and inlet angle on solid separation using CFD simulation. Energy Procedia, 138: 11161121.

Lapple, C. E. (1950): Gravity and centrifugal separation. American Industrial Hygiene Association Quarterly, 11: 40-48. c. f. Sakura G. B. and A. Y. T. Leung (2015): Experimental study of particle collection efficiency of cylindrical inlet type cyclone separator. International Journal of Environmental Science and Development, 6(3): 160-164.

Lapple, C. E. (1951a): Processes use many collector types. Chemical Engineering, 58: 144-151.

Lapple, C. E. (1951b): Dust and mist collection. Air Pollution Abatement Manual, Manufacturing Chemists Association, Washington, D.C. USA. c. f. Surjosatyo, A.; A. Respati and H. Dafiqurrohman (2017): Analysis of the influence of vortexbinder dimension on cyclone separator performance in biomass gasification system. Procedia Engineering, 170: 154-161.

Leith, D. and W. Licht (1972): The collection efficiency of cyclone type particle collectors - A new theoretical approach. American Institute of Chemical Engineers journal, Symposium Series, 126(68): 196-206.

Obermair, S.; J. Woisetschlager and G. Staudinger (2003): Investigation of the flow pattern in different dust outlet geometries of a gas cyclone by laser doppler anemometry. Powder Technol., 138: 239-251.

Palma, R. L. (1978): Slide-mounting of Lice: A detailed description of the Canada Balsam technique. The New Zealand Entomologist, 6(4): 432-436. 
Pandya, D. (2010): A low cost micro scale cyclone separator- design and computational fluid dynamics analysis. M.Sc. Thesis, aerospace engineering, UMI 1480855, University of texas at arlington, USA. PP: 63.

Qian, F.; J. Zhang and M. Zhang (2006): Effects of the prolonged vertical tube on the separation performance of a cyclone. Journal of Hazardous Materials, B136: 822-829.

Rietema, K. (1959): Het mechanisme van de afscheiding van fijnverdeelde stoffen in cyclonen (in dutch). De Ingenieur, 71(39): 59-65. C. f. Elsayed, K. (2011): Analysis and optimization of cyclone separators geometry using RANS and LES methodologies. Ph.D. Thesis, Department of Mechanical Engineering, Faculty of Engineering, Vrije University. Brussel, Belgium.

Schnell, K. B. and C. A. Brown (2002): Cyclone design. Air pollution control technology, Chapter 21. Handbook, Edited by Frank, K., CRC Press LLC, Florida, USA.

Shepherd, C. B. and C. E. Lapple (1939): Air pollution control: A design approach, In Cyclones. $2^{\text {nd }}$ Edition, Woveland Press Inc., Illinois, USA. Pp 127-139.

Spatz, C. (2008): Basic statistics: Tales of distributions. $9^{\text {th }}$ Edition, Belmont, CA: Thomson Wadsworth, ISBN- 10: 0-495-50218-9. USA.

Swaray, M. S. G. and F. Hamdullahpur (2004): A new semi-empirical model for predicting particulate collection effciency in low-to-high temperature gas cyclone separators. Advanced Powder Technol., 15(2): 137-164.

Tan, Z. (2008): An analytical model for the fractional efficiency of a uniflow cyclone with a tangential inlet. Powder Technology, 183: 147-151.

Tantar, A. A.; E. Tantar; P. Bouvry; P. Del Moral; P. Legrand; C. A. C. Coello and O. Schütze (2014): EVOLVE-A bridge between probability, set oriented numerics and evolutionary computation. Springer International Publishing Switzerland. e-ISBN 978-3-31907494-8. PP: 414. 
Wang, B.; D. Xu; K. Chu and A. Yu (2006): Numerical study of gassolid flow in a cyclone separator. Applied Mathematical Modelling, 30: 1326-1342.

Wang, L. (2004): Theoretical study of cyclone design, Ph.D. Thesis, Texas A\&M University, College Station, USA. PP: 137.

Wang, L.; C. B. Parnell; B. W. Shaw and R. E. Lacey (2003): Analysis of cyclone collection efficiency. ASAE Annual International Meeting, Paper Number: 034114. pp: 1-10.

Yeung, E. C. T.; C. Stasolla; M. J. Sumner and B. Q. Huang (2015):

Plant microtechniques and protocols. ISBN 978-3-319-19944-3 (eBook). Canada.

Zhu, Y. and K. Lee (1999): Experimental study on small cyclones operating at high flowrates. Journal of Aerosol Science, 30: 13031315.

\section{الملخص العربى}

العوامل التصميمية والتشغيلية المثلى المؤثرة على عملية فصل ردة القمح

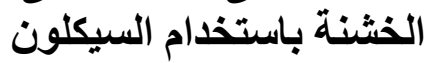

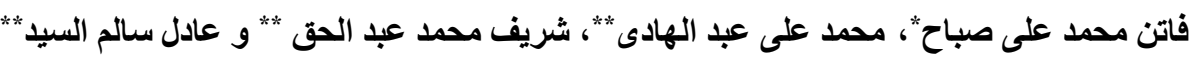

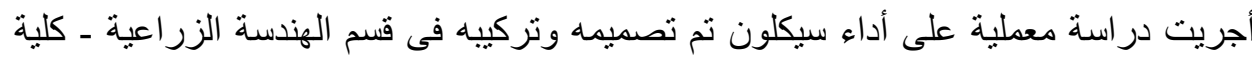

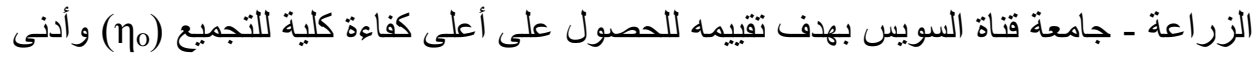

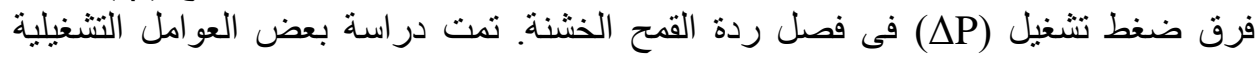

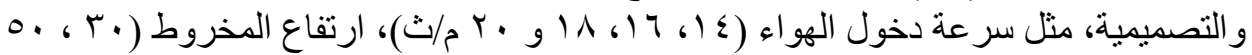

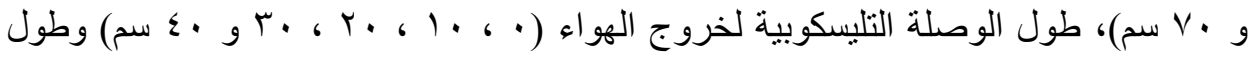

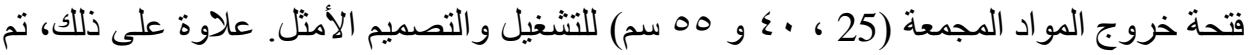

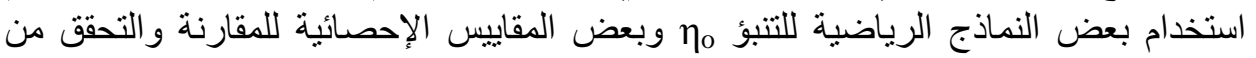
صحة القيم المتنبأ بها مع النتائج المقاسة.

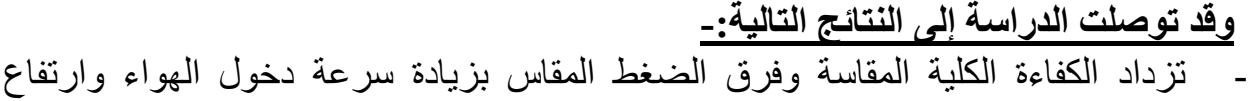

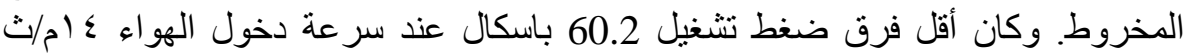

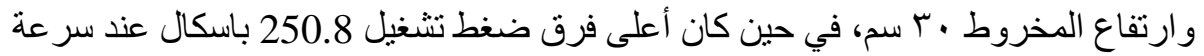

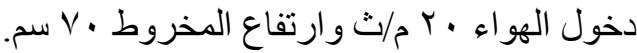

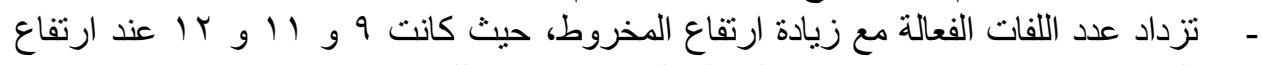

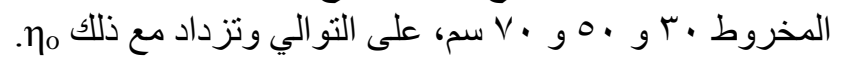

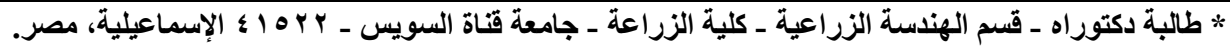
** * أستاذ الهندسة الزراعية ـ قسم الهندسة الزراعية ـ كلية الزراعة ـ جامعة قناة السويس. 
علاوة على ذلك، تزداد ارتفاعات المخروط وأطوال فتحة خروج المواد ادو المجمعة وأطوال الوصلة التليسكوبية

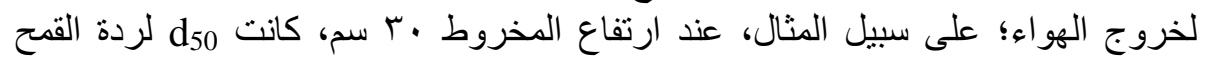

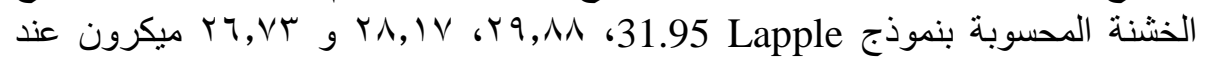

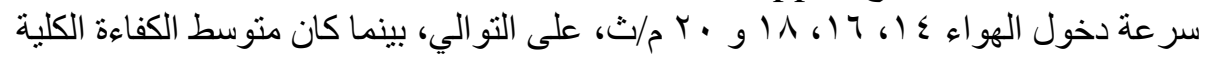

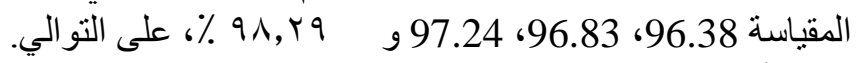

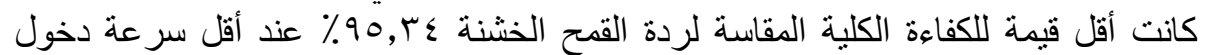

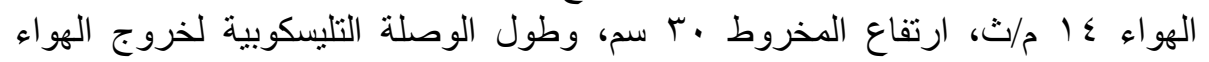

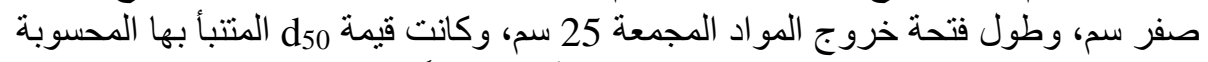

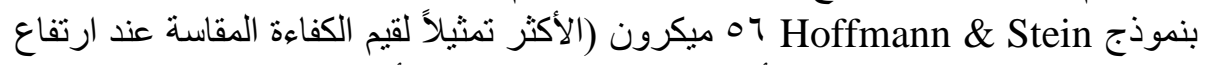

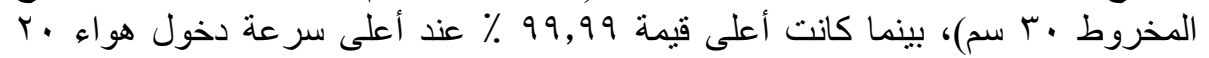

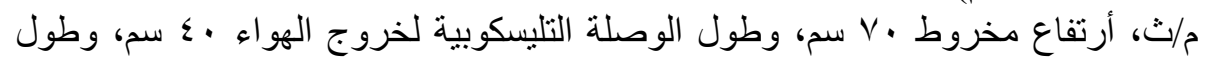

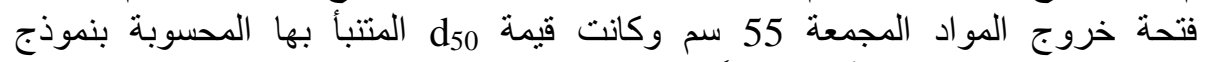
23 Lapple

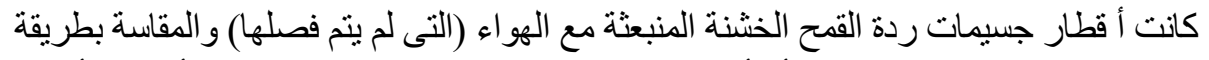

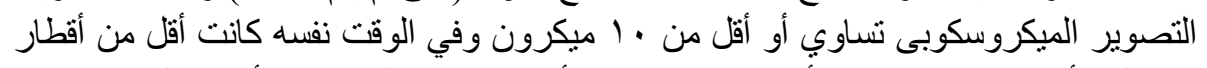

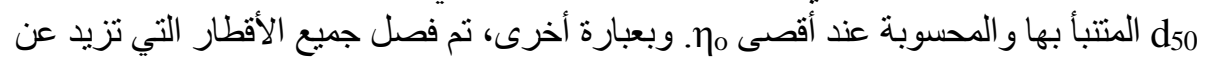
• أ ميكرون وتجميعها في السيكلون.

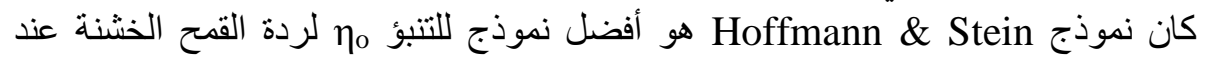

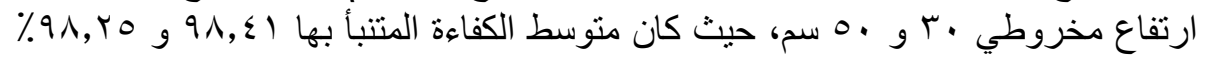

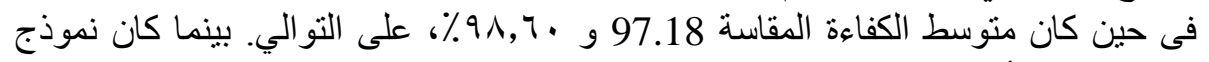
Lapple

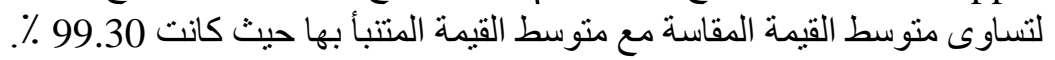

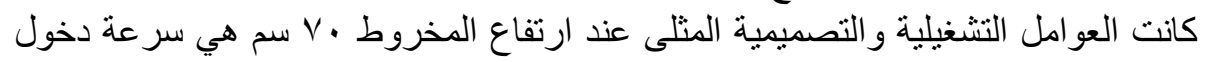

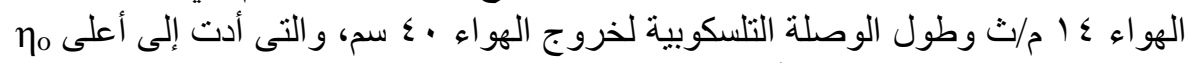

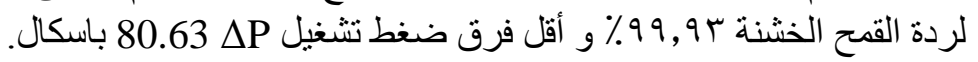

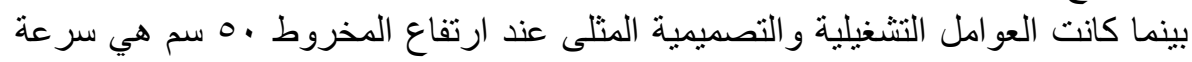

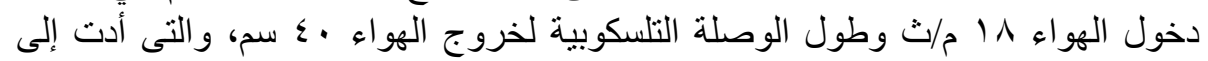

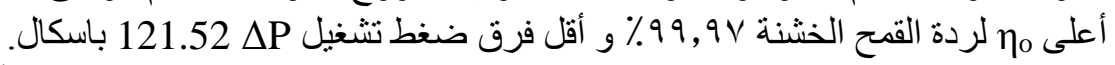

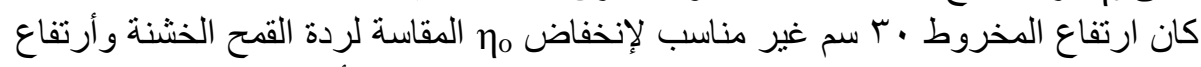
فرق ضغط نشغيل DP المقاس عند كل سرعات دخول الهواء و أطو ال الوصلة التلسكوبية

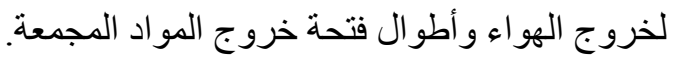
أدى استخدام طول الوصلة التلسكوبية لخروج الهواد الهواء لهوبة صفر سم عند جميع أرتفاعات

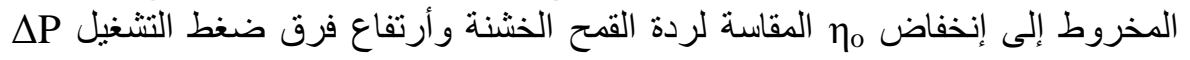
المقاس. 